\title{
Para uma história dos concursos de beleza trans: a criação de memórias e tradição para um certame voltado para travestis e mulheres transexuais*
}

\author{
Aureliano Lopes da Silva Junior**
}

\section{Resumo}

Este artigo procura narrar a história contada sobre três edições do concurso de beleza Miss Boneca Pop (1974-76), certame para travestis realizado na cidade do Rio de Janeiro nos anos de 1974, 1975 e 1976. No ano de 2012, tais concursos foram rememorados com o objetivo de dar certa legitimidade e tradição ao Miss $\mathrm{T}$ Brasil, concurso de beleza para travestis e mulheres transexuais que então se iniciava. Fazendo uso de matérias jornalísticas da época, fotos pessoais e narrativa de uma candidata de duas dessas edições, e bibliografia pertinente aos temas, procuro aqui fazer a arqueologia do Miss Boneca Pop em sua relação com o Miss T Brasil (2012-15), em especial na tradição que este criou para si com base naquele.

Palavras-chave: Concursos de beleza, Travestilidade, Memória, Miss T Brasil, Miss Boneca Pop.

* Recebido em 05 de julho de 2016, aceito em 8 de março de 2017.

** Pesquisador do Laboratório Integrado em Diversidade Sexual e de Gênero, Políticas e Direitos - LIDIS/UERJ, Rio de Janeiro-RJ, Brasil. aurelianolopes@gmail.com 
For a History of Transgender Beauty Pageant: The Creation of Memories and a Tradition for a Beauty Competition for Travestis and Transgender Women

\begin{abstract}
The present article aims to narrate the history about three editions of the Miss Boneca Pop (1974-76), beauty pageant for travestis held in the city of Rio de Janeiro in the years 1974, 1975 and 1976. In the year of 2012, these beauty pageants were remembered with the aim to create some legitimacy and tradition to Miss T Brasil, beauty pageant for travestis and transgender women which then was beginning. Making use of newspaper articles; personal photos and narrative of a candidate of two of this editions; and related literature, I intend to do an archeology of the Miss Boneca Pop in relation with Miss T Brasil (2012-15), specially in the tradition that this one has created based in the first one.
\end{abstract}

Keywords: Beauty pageant, Travesti, Memory, Miss T Brasil, Miss Boneca Pop. 


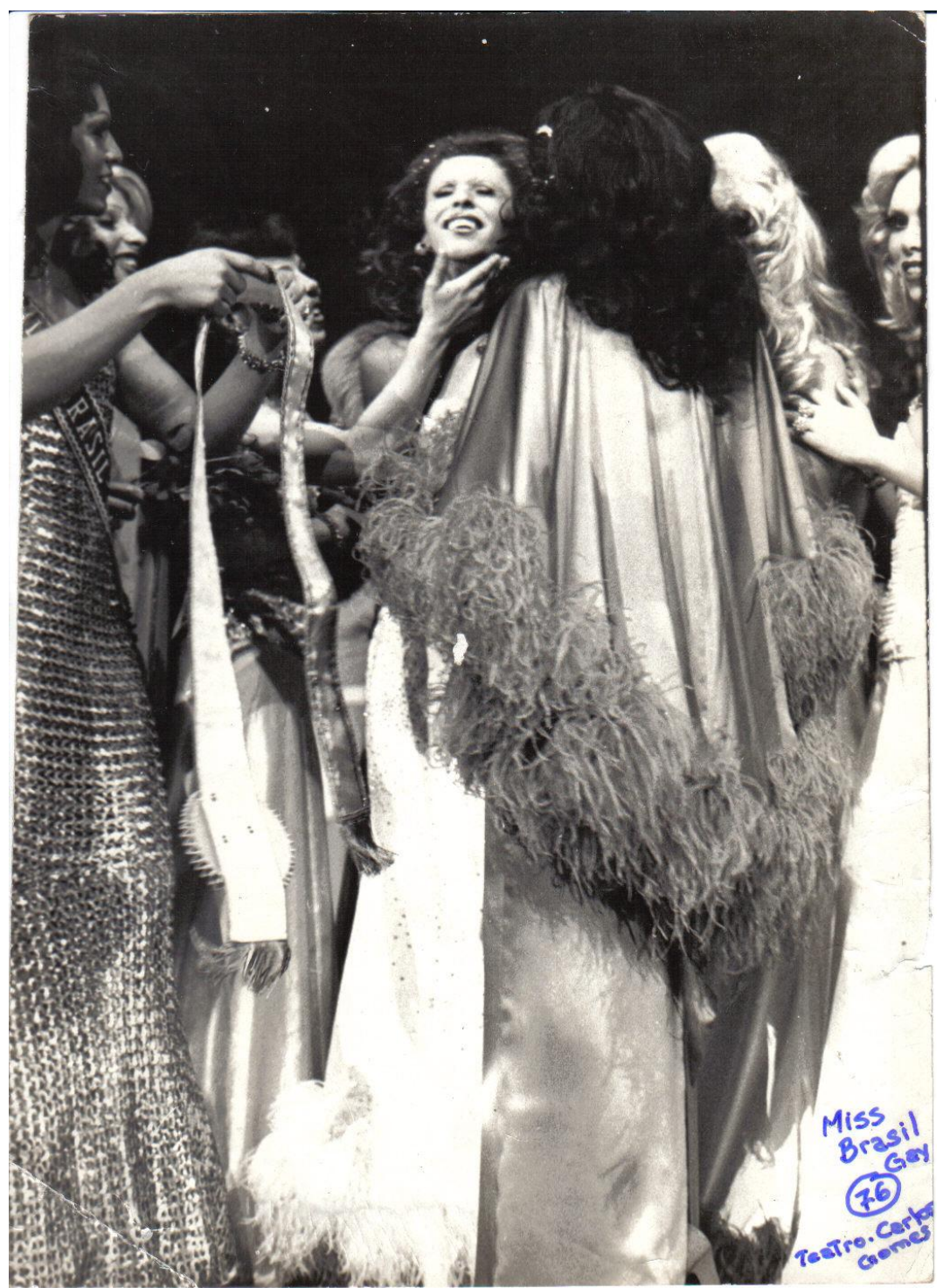

Figura 1 - Cláudia Celeste sendo coroada Miss Brasil (Pop) 1976. Acervo pessoal. 
À Majorie Marchi (in memoriam, 1974-2016), a dona da história.

No dia 30 de outubro de 2012, realizava-se no Teatro João Caetano, na cidade do Rio de Janeiro, a primeira edição do concurso Miss T Brasil. Conforme divulgado em seu site oficial, esse concurso caracterizava-se como "uma ação proposta pela Associação de Travestis e Transexuais do RJ, criada por 'Majorie Marchi', para visibilizar positivamente os segmentos de Travestis e Transexuais, realizando um Certame de beleza específico a nível nacional para estes segmentos" (Miss T, 2012, aspas no original). ${ }^{1}$ Tal caracterização mencionava ainda uma "bem sucedida estratégia internacional em Direitos Humanos via atividade cultural objetivando prioritariamente proporcionar visibilidade positiva para Travestis e Transexuais" (Miss T, 2012), de modo a reforçar a ideia de criar uma visibilidade positiva a partir dos diversos concursos de beleza trans ${ }^{2}$ realizados ao redor do mundo.

1 Informações disponíveis em http://www.misstbrasil.com.br - acesso em 04 set 2012. Esse site foi desativado logo após a primeira edição, tendo migrado em 2013 para o endereço http://misstbrasil.blogspot.com.br/ e, posteriormente, para http://www.mistbrasil.com. Ressalto que a rede social Facebook foi bastante utilizada para a divulgação do concurso por meio da página https://www.facebook.com/MissTBrasilOficial/ e, principalmente, do perfil pessoal de Majorie Marchi.

2 O termo/qualificativo "trans" é categoria do próprio campo, que o utilizava de forma indiscriminada para dizer de uma "beleza trans", "cultura trans", "concurso de beleza trans", etc. Além disso, o termo "trans" aparecia como um grande guarda-chuva para nomear travestis e mulheres transexuais sem estabelecer maiores diferenciações entre tais categorias identitárias. Utilizarei tais termos entre aspas quando se tratar de expressão "nativa", porém também o usarei como um grande guarda-chuva analítico, de modo a seguir seu uso "nativo". O termo travesti também será utilizado como categoria "nativa" e analítica, sendo que, anacronicamente, lançarei mão dele para nomear toda e qualquer "identidade trans" das décadas de 1960-70 nesse contexto dos concursos de beleza "trans" por ser essa a forma com que minhas informantes e entrevistadas olhavam para suas (e/ou de outrem) identidades de gênero do passado. Ainda que, como postula Rogério Costa (2010) e, mais recentemente, Thiago Soliva (2016), nas décadas mencionadas anteriormente "travesti" não possuía um caráter identitário 
Presentemente, encontramos uma ampla gama de concursos e competições visando eleger "a mais bela", segundo determinados e diversificados recortes possíveis. O Miss T Brasil ou apenas Miss $\mathrm{T}$ - nomeava-se como o primeiro desse tipo em nível nacional e creditava-se como uma versão, para travestis $e$ mulheres transexuais, do concurso Miss Brasil para mulheres cisgênero. ${ }^{3}$ Inspirado, então, nos tradicionais concursos de Miss Brasil iniciados regular e consecutivamente desde o ano de $1954-$ ainda que diversos concursos de beleza feminina tenham ocorrido no Brasil desde 1900 -, esse concurso de beleza para travestis e mulheres transexuais transformou a ideia de representatividade do Miss Brasil adequando-a a possíveis temas e pautas do grupo que agora visava representar. Porém, mantinha a noção da eleição de uma beleza segundo normas e padrões sociais tidos como ideais. O Miss T Brasil volta-se para as travestis e mulheres transexuais e pretende, por meio da explícita politização de suas belezas, construir sua legitimidade e representatividade nacional ao eleger a "mais bela trans do Brasil".

Como afirmei anteriormente baseado nas ideias de Cohen, Wilk e Stoeltje (1996), de forma geral,

$e$ poderia se referir mais às homossexualidades masculinas do que à travestilidade, insisto nessa nomeação em respeito e coerência à forma como as memórias foram construídas pelo meu campo. Nesse sentido, historicamente "travesti" tanto pode se referir às homossexualidades masculinas e um possível transformismo como à uma identidade de gênero feminina não passível de ser assumida dessa forma no cotidiano devido às pressões sociais da época (em especial, de ditadura militar).

3 Os termos/categorias cisgênero ou cisgeneridade não apareceram no cotidiano do campo analisado neste trabalho e, por isso, não o utilizarei como "categoria nativa". Porém, como boa parte da produção contemporânea nos campos acadêmico e político dos estudos e/ou questões trans faz uso de tais categorias, as utilizarei de modo analítico. O termo cisgênero é assim conceituado por Letícia Lanz (2015): "Um indivíduo é dito cisgênero (do latim cis = do mesmo lado) quando sua identidade de gênero está em consonância com o gênero que lhe foi atribuído ao nascer, ou seja, quando sua conduta psicossocial, expressa nos atos mais comuns do dia-a-dia, está inteiramente de acordo com o que a sociedade espera de pessoas do seu sexo biológico" (Lanz, 2015). 
concursos de beleza objetivam eleger dentre uma série de candidatas, aquela que melhor representa a ideia que determinado grupo faz de si, o que tanto produz a imagem de coerência interna do grupo em questão, como o visibiliza perante um público e coletivo externo (Lopes, 2013:2).

É nesse sentido que concursos de beleza projetarão uma espécie de comunidade imaginada (Anderson, 2008), a qual tanto será literalmente encarnada ${ }^{4}$ no corpo de suas candidatas, de modo a projetar um modelo ideal do que aquele grupo é ou deveria ser, como também criará um público suposto para tal certame.

Dentre os ideais construídos em um concurso de beleza, talvez o mais notável seja aquele que se refere às construções de gênero ali encarnadas, de modo que um certame desse tipo se constituirá como "espaço de construção de gênero, entendendo-se 'espaço' de uma forma amplamente dialógica, onde há absorção e reforço de modelos e onde contam contextos, atores sociais, estilos, etc." (Batista, 1997:214). Imbricados na produção de determinado feminino ou feminilidade, ideais de beleza e de comportamento e marcadores como nacionalidade, raça/etnia, classe, entre outros possíveis, parecem estar em disputa e em construção em concursos de beleza. O Miss T Brasil lança mão desses marcadores e foca na construção de uma beleza tida como desejável para travestis e mulheres transexuais e sua consequente politização ao almejar uma visibilidade dita positiva para sujeitos

4 O termo encarnado e suas variações serão utilizados neste trabalho no mesmo sentido do conceito de embodiment (Csordas, 2008; Connel, 2012; Ochoa, 2014). Esse termo me pareceu uma melhor tradução de embodiment - conceito proposto por Csordas a partir da ideia de que "o corpo não é um objeto a ser estudado em relação à cultura, mas é o sujeito da cultura; em outras palavras, a base existencial da cultura" (2008:102, grifos no original) - para o português, principalmente por me parecer trazer mais fortemente a ideia de um corpo tornado possível como materialidade no meio social. Também concebo encarnado como "tendo que ver apenas com a aprendizagem e assimilação feita pelo corpo e só nele observável", como postula Miguel Vale de Almeida (1996:20), apesar desse autor ter traduzido embodiment como "incorporação". 
identificados como trans. Como discute Mário Carvalho (2015), pelo menos nos últimos 10 anos, a construção de determinado tipo de visibilidade $e$ a luta por seu reconhecimento $e$ sua legitimação social têm sido talvez a principal marca do movimento - ou movimentos - de travestis e mulheres transexuais no Brasil.

Um concurso de beleza parece ser um dispositivo ideal para se forjar essa visibilidade vista como positiva, principalmente porque o formato por aquele consagrado no imaginário social é o da exibição de aspirantes à coroa de miss e eleição daquela que será chancelada como a representante de uma nação. Assim, como postula a socióloga Oluwakemi Balogun (2012) baseada nas ideias de Sarah Banet-Weiser (1999),

concursos de beleza, especialmente os nacionais, oferecem um caso singular para se estudar como os ideais de gênero desempenham um papel nos discursos de construção da nação, uma vez que são locais tangíveis na produção da identidade nacional generificada ${ }^{5}$ (Balogun, 2012:358).

A Miss $\mathrm{T}$ Brasil, então, seria aquela que representaria a "população trans", forma como esse coletivo vem sendo concebido pela chamada política LGBT brasileira (Aguião, 2014).

Essa identidade étnica/nacional generificada pode não ter relação com o encarne de uma corporalidade e beleza talvez reconhecidas como a média daquele feminino e grupo em questão, como reivindicava o antropólogo brasileiro Edgar Roquette-Pinto na década de 1930 (1978); ao contrário, o modelo mais presente em concursos de beleza femininos será aquele constituído fenotipicamente como caucasiano, centrado em ideais europeus para a beleza feminina como pele branca, corpo magro e longilíneo, cabelos lisos e traços corporais tidos como "não exagerados" e/ou "proporcionais", de acordo com "termos

5 Tradução livre, no original: "Beauty pageants, particularly national ones, provide a unique case for studying how gendered ideals play a role in nationbuilding discourses since they are tangible sites in the production of gendered national identity" (Balogun, 2012:358). 
nativos" do Miss T Brasil. Como observa Ana Batista (1997), esse feminino muitas vezes será nomeado como "feminino universal" ou "beleza universal", sendo, em muitos casos, visto como o padrão a ser alcançado ou uma espécie de medida a partir da qual toda beleza feminina seria percebida e qualificada.

$\mathrm{O}$ Miss $\mathrm{T}$ Brasil produziu determinada visibilidade $e$ a legitimou socialmente ao inseri-la estrategicamente nessa linguagem que poderíamos identificar como artístico-cultural, além de entender-se como partícipe de uma linhagem mais geral de concursos de beleza. Desde sua proposição, o Miss T concebeu-se como a "versão trans" do tradicional Miss Brasil e ainda criou para si história e tradição que justificavam sua idealização e realização: na mesma Praça Tiradentes, no centro do Rio de Janeiro, onde no Teatro João Caetano aconteceram as duas primeiras edições do Miss T Brasil, fica o Teatro Carlos Gomes, que, nos anos de 1974, 1975 e 1976, foi palco de três edições da competição voltada para travestis vista como a "pré-história" do Miss T Brasil.

Inicialmente nomeado como Miss Brasil, mas tendo que modificar seu nome posteriormente para Miss Pop ou Miss Boneca $\mathrm{Pop}^{6}$, já que aquela nominação se referia aos tradicionais concursos para mulheres cisgênero, tal certame elegia a mais bela dentre aquelas que se travestiam e vivenciavam um gênero feminino, mesmo que não pudesse ser assim sustentado cotidianamente e algumas vezes só fosse permitido em momentos específicos, como festas particulares, bailes de carnaval $e$

${ }^{6}$ Encontrei esses dois nomes em notícias de jornais referentes a tal certame. Sobre o termo "Boneca", Cláudia Celeste afirma que, principalmente na década de 1970: "Tudo era boneca na época, não se chamava travestis nem gay. Falava bonecas. Espetáculo de travestis era espetáculo de bonecas. O pessoal começava a achar que travesti era pejorativo, aí eles começaram a chamar bonecas. Era show de bonecas: 'Bonecas com tudo em cima', 'Bonecas com algo mais', 'O mundo é das bonecas', 'Liberdade para as bonecas'. Era tudo boneca. Concurso de bonecas, entendeu?" (Cláudia Celeste em entrevista ao autor, 2012). Apesar dessa ênfase no termo boneca nos anos 1970, o termo já aparecia em algumas produções teatrais da década anterior (Green, 2000). 
competições de beleza. ${ }^{7} \mathrm{Na}$ história contada pelo Miss T Brasil $-e$ também na produzida neste artigo -, esses concursos realizados na década de 1970 eram nomeados como "concursos de beleza trans", não sendo muito importante como eram identitariamente concebidos naqueles anos. O que importava era trazer à baila o sucesso e o esplendor daquilo que para o discurso do Miss T era tido como uma legítima manifestação artístico-cultural "trans" ou "cultura trans", como desenvolverei na parte final deste texto.

A construção dessas "memórias trans" pelo Miss T Brasil também girou em torno de uma figura em especial: a atriz $e$ cantora Cláudia Celeste. Cláudia foi por mim entrevistada em 2012, antes da realização da primeira edição do Miss T Brasil, na qual trabalharia como produtora artística e coreógrafa. E estaria ali também como homenageada, pois havia sido a vencedora da terceira edição (em 1976) daqueles referidos "concursos trans" da década de 1970. Nesse sentido, este artigo será perpassado pela sempre presente reconstrução do passado quando tocamos o material da memória (Pollak, 1989 e 1992; Bosi, 2003) a partir do que me foi relatado de forma absolutamente teatral e "divina" por Cláudia Celeste, artista que começou sua carreira no início dos anos 1970 e que é uma daquelas pessoas que carrega o teatro e a teatralidade no sangue, nos gestos, no olhar, no falar, no recordar...

7 James Green (2000) também faz menção a tal rede, bem como a concursos de beleza transformistas e a presença de transformistas no espaço do carnaval. Acredito que possa haver relações entre essas experiências de gênero da Rede do jornal $O$ Snob.e aquela dos concursos Miss Pop da década de 1970, até porque a realização de concursos de beleza domésticos era um dos grandes motes daquela Rede. O jornal $O$ Snob foi uma publicação produzida e voltada para homossexuais masculinos entre os anos de 1963 e 1968, na cidade do Rio de Janeiro. Essa publicação acabou por movimentar uma rede de sociabilidade que realizava periodicamente uma série de eventos sociais entre seus membros, com destaque para diversos certames, como mencionarei no texto.

${ }^{8}$ Pretendia entrevistar outras personagens dessa história, porém acabou não sendo possível. Por advertência da própria Cláudia Celeste, não busquei entrevistar o organizador dos concursos da década de 1970, Luiz Garcia, por ele se encontrar à época bastante enfermo e recluso. Também não entrevistei 


\section{"Os Estados brasileiros se apresentam / Nesta festa de alegria e esplendor"}

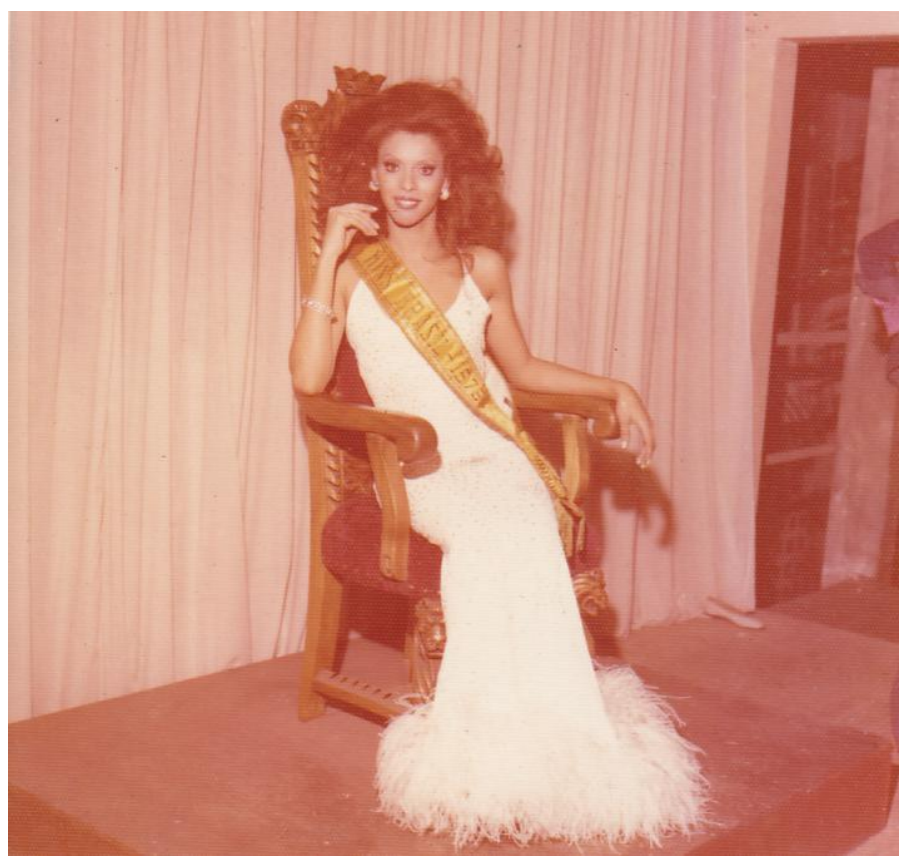

Figura 2 - Cláudia Celeste como a Miss Brasil (Pop) 1976. Acervo pessoal Cláudia Celeste.

Cláudia Celeste, carioca do bairro do Irajá, nascida em 1952, iniciou sua carreira artística em 1973 após trabalhar como

Paulette Loramil, vencedora da primeira edição de 1974, por Cláudia ter me dito que ela se encontrava fora do "circuito trans", em especial o das "antigas" do qual Cláudia faz parte. Em 2015, entrei em contato com Ângela LeClery, coroada Miss Pop em 1975, e ela se dispôs a ser entrevistada, porém por encontrar-se por um longo período fora do Rio de Janeiro e, posteriormente, por eu também ter passado alguns meses fora do país durante o estágio do doutorado sanduíche, não conseguimos nos encontrar. Trago aqui, portanto, o relato de Cláudia Celeste em diálogo tanto com alguns trabalhos que nos ajudam a situar o contexto dos concursos de beleza para travestis de outrora, como com informações obtidas em reportagens e notas jornalísticas que consegui localizar. 
cabeleireira no bairro de Copacabana, Rio de Janeiro. Segundo entrevista concedida à Revista Geni, em 2013,

Em 1973, eu acompanhei uma amiga minha que ia fazer um teste pro teatro de revista. Ela não passou, mas o diretor me perguntou: "Você não vai fazer o teste?". Eu não falei nada, fiquei meio sem graça, e minha amiga disse: "Ela não quer fazer o teste porque é travesti". Aí parou tudo! Eu fui selecionada, mas naquela época estavam proibidos os espetáculos de travestis, ficaram proibidos no teatro de 1969 a 1973. Então me levaram pras boates e eu comecei a dançar como go-go girl (Cláudia Celeste citada por Silva; Visnadi; e Mohallem, 2013).

Trabalhando no corpo de bailarinas de diversos espetáculos, principalmente aqueles nos moldes do Teatro de Revista, Cláudia foi se inserindo no meio artístico, tanto em shows de travestis como em montagens nas quais, devido à sua feminilidade, "passava batida" como mulher em espetáculos com elenco formado exclusivamente por mulheres cisgênero. Seu primeiro grande espetáculo foi "O mundo é das bonecas" em 1973, no Teatro Rival, na Cinelândia, com Jane di Castro, Geórgia Bengston e outras artistas travestis. Cláudia relembra com muito humor de um momento anedótico e marcante de sua carreira, isso já no ano de 1977:

Eu tava [sic] fazendo o teatro da Brigitte Blair [...] com um grupo de mulheres e tudo [...] era um balé na cadeira que eu fazia com as bailarinas. E que o diretor da novela foi lá [...] e queria botar uma cena da novela [Espelho Mágico, exibida pela Rede Globo em 1977] [...] Lima Duarte que fazia um cara que era de Teatro de Revista e a Sônia Braga [...] era uma menina que fazia tudo pra subir na carreira. [...] Como eu era a figura central, aí ele gostou do meu número e falou: "Vamos usar esse número" [...] E aí eu fazia um número e tudo e tinha uma participaçãozinha, falava, eu dizia pra... ele falava assim: "Você explica a coreografia - não tinha texto - explica a coreografia pra 
Sônia Braga, só que tu não vai chamar ela de Sônia, chama ela de Cinthia". [...] E ele foi filmando e eu fui explicando a coreografia: "Você pega aqui, você sobe, você desce, você vem, vem um, dois, três, quatro, cinco, seis, sete oito. Dois, dois, três quatro, cinco, seis, sete oito. Quatro dois três quatro cinco seis sete oito...". "Na cadeira, vem pra trás, não sei o que, subiu, [joga o] boá, pá". A gente usava umas perucas e tudo, era balé de mulher e eu tava passando porque eu era uma das meninas do balé. Tanto que o Daniel Filho nem sabia que eu era travesti, que a Brigitte [Blair] não falou nada. Ninguém perguntou [risos]. Eu também não falei nada, ninguém perguntou. Então passou. Quando fui ver o jornal [Figura 3] que tinha [...] a coluna gay que era todos meus amigos, sabia que eu era, claro. Quando me viram na televisão, querido, foi um sucesso, porque a comunidade gay toda: "O que? [com bastante ênfase] Claudia Celeste está na novela!!!". Porque era proibido, nem Rogéria que era famosa podia, nem Valéria, que era famosa. Por que que eu estava e tudo? Aí essa minha amiga ela botou: "Celeste, maravilhosa e tudo". Quando ela botou isso no jornal, pronto, a imprensa inteira! Quando eu cheguei no teatro tava [sic] aqueles focos, "plim plim", parecia Hollywood. Eu chegando pra trabalhar e o pessoal me fotografando. "Que que é isso que tá acontecendo?" "Não, você agora é uma celebridade, apareceu na televisão". "Meu Deus, eu não fiz nada, eu fiz uma ponta". Não, mas não sei o que, proibido, não, época dos militares, não sei o que. Conclusão: eu ia fazer os outros capítulos, teve que tirar. Teve que cortar a cena. Apareci em dois capítulos, no terceiro já não pude aparecer (Cláudia Celeste em entrevista ao autor, em 05 de outubro de 2012). 


\begin{abstract}
Um dos nossos melhores e mais bonitos travestis, CLAU. DIA CELESTE, vencedora in clusive do Concurso Miss Brasil Gay ano passado, está tendo uma participação na novela da TV Globo, "Espelho Mági$\mathrm{Co}^{\prime \prime}$, onde aparece como uma a principal corista do Teatro de Revista onde trabalham LIMA DUARTE $~$ D DJENANE MA. CHADO Na ultima semana ela apareceu em vários capítulos, fazendo dublagem e ensinando coreografia à atriz SONIA BRAGA. Eu só não entendo por que a grande ROGERIA sempre foi proibida de aparecer no vídeo pela censura e outras como GEORGIA BEN GSTON, SHIRLEY MONTE. NEGRO, VALERIA E MARIA LEOPOLDINA também não puderam aceitar os convites que receberam. Ser travesti é uma arte, das mais dificeis, mas se proibem algumas, en. tão a Globo não tem o direito de usar outra, embora todas merecam, pois a proibicão válida pra todo mundo. Quem acompanhar a novela pode constatar.
\end{abstract}

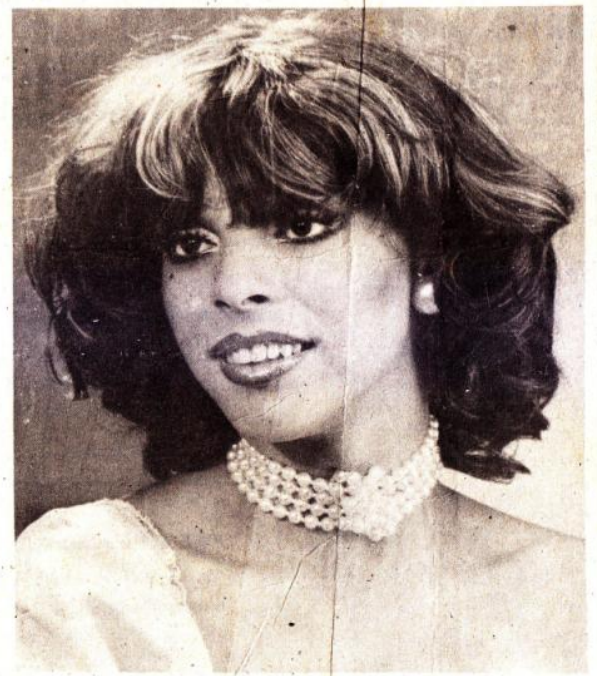

Figura 3 - Coluna de jornal sobre participação de Cláudia Celeste na novela "Espelho Mágico". Fonte: não identificada. Acervo pessoal Cláudia Celeste.

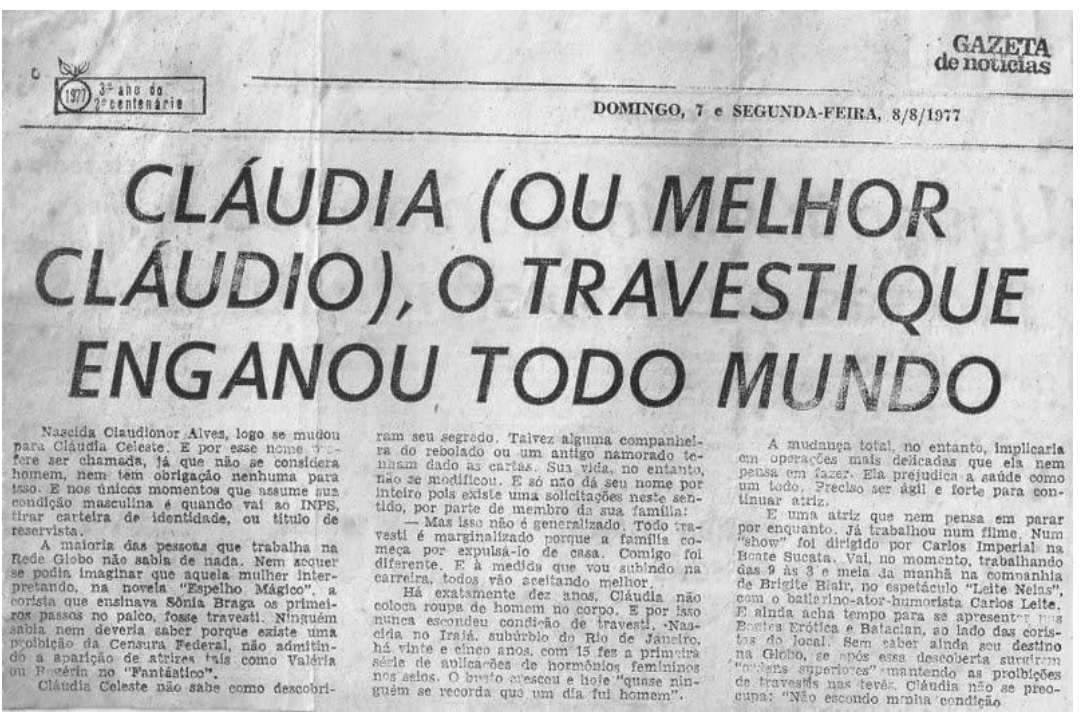

Figura 4 - Nota do periódico Gazeta de Notícias sobre a participação de Cláudia Celeste na novela "Espelho Mágico", da TV Globo. Acervo pessoal Cláudia Celeste. 
Na nota (Figura 3) que teria provocado todo o imbróglio com sua participação na telenovela global ${ }^{9}$, Cláudia é anunciada como vencedora do "Concurso Miss Brasil Gay"10 de 1976, certame que apareceu em sua trajetória tanto por sua veia artística como por ser uma possibilidade para vivenciar sua feminilidade em um espaço público, ainda que diverso da rua, já que sair "de mulher" era arriscado e proibido. "Já fui presa na Cinelândia porque eu tava [sic] vestida de mulher [risos]. No meio da rua andando, entendeu? Prendiam, atentado ao pudor" (Cláudia Celeste em entrevista ao autor, em 05 de outubro de 2012). ${ }^{11}$

Cláudia também havia participado da primeira edição do mesmo concurso de beleza em 1974, na qual ficou em terceiro

9 Na segunda nota sobre a participação de Cláudia Celeste na novela "Espelho Mágico", da TV Globo (Figura 4), aparece a informação de que a "revelação" de que Cláudia era uma travesti podia ter sido feita por uma amiga ou ex-namorado dessa atriz. Na entrevista de Cláudia cedida a mim em 2012, tal "revelação" é creditada à nota jornalística (Figura 3). Ambos os materiais pertencem ao acervo pessoal de Cláudia Celeste e aparentemente não são vistos como contraditórios por ela.

${ }^{10}$ Essa foi a única menção ao concurso como "gay" encontrada, $e$ talvez o termo tenha sido utilizado por a coluna ter sido escrita por "entendidos" - forma como homossexuais se nomeavam e/ou eram identificados desde os anos de 1940 (ver Green, 2000) - e/ou "gays",. Nota-se ainda que, como destaca Rogério Costa (2010), na rede de $O$ Snob o termo gay aparece pela primeira vez em 1963 após um de seus membros ter voltado de viagem aos Estados Unidos. "Gay" passou a ser reivindicado mais fortemente como forma de se nomear a partir de 1965, causando conflitos por ser uma proposta de substituição ao termo "bicha" $e$ também como oposição a "travesti". Costa frisa que mesmo assim a conotação do nome "gay" era a de um terceiro sexo. Cabe ressaltar ainda que o concurso transformista que se iniciaria em 1978, na cidade de Juiz de Fora, e que de certa forma foi uma continuidade do Miss Pop, levou o termo "gay" no nome, Miss Brasil Gay.

${ }^{11}$ Cabe ressaltar que o vestir-se "de mulher" aqui parece diverso daquele que diz respeito ao crossdressing, como descrito por Anna Paula Vencato (2013), já que no primeiro parece estar suposta uma identidade travestis/"trans" que poderia sofrer sanções policiais/legais caso fosse assim exibida em público, ao passo que no segundo há uma prática prazerosa em um "se montar" ou "se vestir" como uma mulher em determinados contextos, independentemente de suas identidades de gênero e/ou orientações sexuais. 
lugar. Segundo ela, as competições começaram de um modo mais informal principalmente nos bancos da Cinelândia, no centro da cidade do Rio de Janeiro:

Começou as bichas ${ }^{12}$ se reunindo [...] na Lapa, ou então nos bancos na Cinelândia. E ali coroavam e tudo. O povo frequentava, marcava um horário de noite. Um sábado, por exemplo, [...] e as amigas se reuniam, uma era cabeleireira daquilo, a outra era não sei o que. Elas se conheciam, claro. E se juntava e aí fazia o concurso ali (Cláudia Celeste, 2012).

Nesses momentos, todas iam montadas $e$ a festa terminava quando tinham que sair "correndo porque a polícia chegava $e$ tinha que sair correndo, entendeu? [risos] Faziam em casa [também], mas os concursos de Miss eram na rua" (Cláudia Celeste em entrevista ao autor, em 05 de outubro de 2012).

Rogério Costa (2010) em seu trabalho sobre o jornal $O$ Snob, publicação produzida e voltada para homossexuais masculinos pertencentes a essa rede de sociabilidade entre os anos de 1963 e 1968 na cidade do Rio de Janeiro, menciona os concursos realizados em ambientes domésticos. Além de seus frequentadores se assumirem como aficionados pelo concurso Miss Brasil - que talvez tenha tido seu auge de popularidade no país também na década de 1960 e na anterior -, essa rede de

\footnotetext{
${ }^{12}$ Cláudia Celeste mescla termos no feminino e no masculino para se referir a si bem como a outrem nesse contexto da década de 1970, ainda que, em muitos contextos, o uso do pronome masculino por travestis e mulheres transexuais para se referir a si ou a outras pessoas que fariam parte da "população trans" feminina possa ser visto como um xingamento (Barbosa, 2010) ou uma despolitização (Carvalho, 2015). Além disso, utiliza diversos termos para se referir às pessoas, como "bicha" e "gay" que tanto pode estar referido a homossexuais masculinos quanto àquelas que posteriormente se assumiriam travestis, mas que ainda não o haviam feito por completo pela impossibilidade do contexto da época. Mantive a forma como falada por ela e penso ser esse um indicativo de concepções $e$ possibilidades de exercício da travestilidade naquela época.
} 
sociabilidade realizava seus próprios certames, como o autor descreve:

Nos primeiros anos, todavia, eram fortemente influenciados pelos concursos oficiais, $e$ as candidatas proclamavam em sua inscrição os estados que defendiam (miss Pernambuco, miss Guanabara etc.) ou se apresentavam como representantes de algum clube. Os organizadores estruturavam esses concursos em torno de dois tipos: em "travesti" e "gay" (como "terceiro sexo") relacionados, o primeiro, à vestimenta feminina $e$ aos aparatos de maquiagem (Miss luxo, Miss elegância, por exemplo), o segundo, a trajes masculinos, valorizando a elegância cotidiana das "bichas" (Miss Praiana, Concurso de camisa, entre outros). [...] A produção dos desfiles envolvia várias estratégias de arrecadação de dinheiro para a realização do concurso: leilões de objetos doados pelos participantes, jantares de organização, entre outros encontros. A própria organização produzia assunto durante meses, e tudo virava notícia em O Snob. As "bonecas" concorrentes tinham considerável despesa extra, incluindo produção das roupas de desfile, contratação de maquiladores e cabeleireiros, aluguel de perucas; o alto custo da produção para "elas", era largamente compensado, pois as vencedoras eram destaques em várias edições do jornal, tendo até a possibilidade de ser capa; ademais como relata um participante da festa na qual ocorreu o certame de Miss Praiana, "não foi apenas um concurso de traje típico ou de plástica. Foi além de tudo isso um encontro de amigos, com bate-papo variados entre um drink e um cigarro". A solidariedade entre os membros era ponto relevante desses eventos, com a afirmação de afinidades compartilháveis (Costa, 2010:81-82).

Costa destaca uma série de concursos realizados por essa rede entre os anos de 1963 e 1968, como o "Miss Traje Típico, Miss Inverno e Miss Elegância" (2010:83) em 1963, 
Miss Snob e Miss Inverno (patrocinados pelo $O$ Snob), Miss Subúrbio à Noite, Miss Fatos e Fofocas (BA), Miss Objetiva, Miss Imprensa (patrocinado pelos jornais), Miss Brasil (patrocinado por $O$ Mito e pelo grupo C-10), Miss Felinos, Favorita dos Pelicanos (eleita pelo grupo formado só por 'entendidos') e Miss Festival [em 1967] (2010:83-84).

Ou ainda novos concursos realizados em 1968, após o aparecimento de novos jornais nos moldes daqueles presentes nesta rede, como o "Miss Centauro, Miss O Grupo, Miss Elegância (da Turma da Zona Norte) e Miss Passarela, realizado de improviso numa festa" (Costa, 2010:83). Todos esses eram concursos tidos como mais domésticos, ainda que pudessem ser realizados em algum tipo de clube. ${ }^{13}$ Rogério Costa destaca que o principal objetivo dos concursos era a produção de ambientes festivos e de sociabilidade para a rede. Ele ainda chega a afirmar que "foi, aliás, justamente o desacordo quanto ao resultado do Miss Traje Típico [em 1963] que desencadeou a elaboração do primeiro número do jornal" (Costa, 2010:82) da rede de O Snob.

Os concursos de beleza representavam um momento bastante esperado, seja o Miss Brasil que fazia parte do calendário

${ }^{13} \mathrm{Em}$ seu trabalho sobre a Turma OK, grupo carioca de sociabilidade homossexual, fundado em 1961 e que compunha a rede de $O$ Snob, Thiago Soliva (2012) menciona a importância do espaço doméstico dos apartamentos para os diversos homossexuais masculinos que viviam nesta mesma época no Rio de Janeiro. As diversas "Turmas" então formadas na cidade se encontravam em reuniões domésticas regulares que "representavam oportunidades para travar contato com indivíduos que compartilhavam experiências comuns, baseadas no reconhecimento de 'outros' como 'iguais'" (Soliva, 2012:42). Essa experiência da criação de uma rede de sociabilidade entre "iguais" é a marca da Turma OK desde seu início, o que é reiterado na descrição que fazem de si: "A Turma OK não é um grupo de militância gay, nem mesmo uma boate ou bar gay. É um clube social, estritamente familiar, na tradição carioca gay do centro do Rio. [...] É uma verdadeira confraria gay, localizada na Lapa. [...] A Turma OK nasceu, como essas pequenas coletividades, numa das costumeiras reuniões que se realizavam semanalmente ou, no máximo, de 15 em 15 dias no apartamento de Antônio Peres, no Edifício Varsóvia, situado na rua Almirante Tamandaré. Exatamente no dia 13 de janeiro de 1961." (Turma OK, 2017). 
de passeio dos grupos e/ou os próprios certames produzidos em festas maiores pelas "turmas". Sobre o primeiro, Thiago Soliva (2012) traz um relato de Anuar Fahar, um dos membros da Turma OK e Rede de $O S n o b$, que descreve a importância e o prazer de participar da plateia nos desfiles de Miss Brasil da década de 1950 no Ginásio do Maracanãzinho, no Rio de Janeiro:

O chique, o maravilhoso era você sentar-se na arquibancada, no último lance da arquibancada... No último lance, as "deslumbradas", aquelas bichas... aquelas louquinhas, elas desfilavam lá em cima, e cá embaixo nós todas lindas, maravilhosas, modelos lindas. Cada uma fazia a sua roupa para ir no coisa [Miss Brasil], tinha gente lá... de estola de pele, mil coisas (Fahar citado por Soliva, 2012:34).

O concurso de Miss Brasil mobilizava as redes de sociabilidade homossexual masculina, que possuíam fãs aficionados por esse tradicional certame. Como parte do público do Miss Brasil, "bichas" aproveitavam o espaço das arquibancadas do ginásio do Maracanãzinho, no Rio de Janeiro, para exercer um pouco de uma estética camp $p^{14}$, como James Green (2000) caracteriza esses momentos. Ali, ensaiavam e visibilizavam esses "desfiles" domésticos que, mesmo que lá do alto da arquibancada, ganhavam espaço naquele tradicional ginásio do Miss Brasil.

Os concursos promovidos pela Turma OK - e possivelmente outras turmas - seguiam o que foi descrito acima por Rogério Costa (2010) e os certames da rede de O Snob, da qual aquela fazia parte. Entre idas e vindas, mas mantendo as relações de amizade ali construídas, como observa Thiago Soliva (2012), a Turma OK realizou atividades e concursos para seus membros desde sua fundação, em 1961, período no qual o apartamento de um dos sócios era o espaço para todos os eventos dos

\footnotetext{
${ }^{14}$ Camp poderia ser literalmente traduzido como "afetação" e se relaciona à estilização de trejeitos que poderiam ser vistos como de gays e/ou homossexuais (masculinos).
} 
autoproclamados "Okeis". A partir de 1977, o grupo passou a contar com uma sede no bairro da Lapa ${ }^{15}$, onde os concursos passaram a ser realizados. Ali, além dos antigos, foram criados novos concursos, shows e espetáculos. Os concursos podiam ganhar diferentes nominações com os tradicionais termos "miss" ou "rainha", como "Rainha da Primavera" ou "Rainha do Carnaval" e variaram ao longo dos anos. No período de trabalho de campo de Soliva, entre 2010 e 2012, havia os seguintes concursos realizados regularmente e considerados importantes pela Turma OK: "Lady OK, Mister OK, Rainha OK, Rainha da Primavera e Musa OK" (Soliva, 2012:20).

Os diversos concursos realizados nos apartamentos de homossexuais masculinos na cidade do Rio de Janeiro ganharam a rua e uma grande produção no ano de 1974, com o Miss Brasil (Gay e/ou Travesti) sendo realizado no Teatro Carlos Gomes, como nos conta Cláudia Celeste:

O primeiro, o primeiro Miss Brasil, né, que teve assim uma repercussão. Porque já existia, claro, já existia nos bancos da Cinelândia. Elas já faziam ali, na Cinelândia, as brincadeiras delas e tudo. Mas tomou uma proporção assim legal foi no Teatro Carlos Gomes. O Luiz Garcia que era o produtor do evento se juntava com uns amigos $e$ tudo $e$ eles organizavam a coisa toda. O primeiro foi em 74, 1974, onde ganhou a Paulette Loramil, que era uma trans loira bonita, muito chique. Ela era cabeleireira já na época. Ganhou o primeiro lugar. Eu participei do concurso, eu tirei o terceiro lugar, como Miss Rio de Janeiro. Aloma, que é de São Paulo, que representou São Paulo e tudo [...] tirou em quarto lugar nessa época. A Esmeralda, era uma grande Esmeralda de Paris e não sei o que, ela tirou em segundo lugar. Que ela era muito linda [...] cor de jambo, assim, uma coisa assim, uma coisa linda. Quando ela entrou que pentearam ela, que puseram cabelo, a maquiagem, tudo. Uma coisa, parecia uma aparição, parecia uma mistura de

\footnotetext{
${ }^{15}$ Cabe ressaltar que a sede da Turma OK já ocupou alguns endereços diferentes, mas desde 1977 manteve-se no bairro da Lapa.
} 
Esmeralda Barros, que era uma mulata famosa da época, com Marina Montini, que também era outra mulata do Di Cavalcanti. E ela era... era uma pessoa, assim, muito agradável, entendeu? Mas de uma beleza impressionante (Cláudia Celeste em entrevista ao autor, em 05 de outubro de 2012).

Cláudia Celeste também versou sobre a dinâmica desses concursos que, segundo ela, contavam com traje de gala e traje típico - tanto confeccionados pelas candidatas como por um grande costureiro contratado. Ainda era possível as candidatas ganharem roupas para os concursos e para espetáculos teatrais de clientes socialites que frequentavam os salões de beleza em que algumas trabalhavam:

Nós que fazíamos os trajes; cada uma fazia o seu ou produzia, gastava o seu dinheiro, mandava fazer na costureira, no figurinista. Muitos que eram costureiros ajudavam, entendeu? Ou então aquelas que tinham um bom conhecimento e tudo e tinham costureiros famosos que faziam os trajes e davam pra elas. Mulheres que eram as clientes dele davam os vestidos. Vestido de [...] uma grande socialite, ela dava os vestidos dela de presente. [Uma amiga] ganhou presente. [...] ele foi um dos maiores cabeleireiros do Brasil. As clientes dele davam vestidos. Aquelas mulheres da alta sociedade davam vestido de presente pra ele. Tinham prazer de ver ele vestido de mulher. E aí davam roupas, ajudava (Cláudia Celeste em entrevista ao autor, em 05 de outubro de 2012).

Essas socialites que ajudavam suas cabeleireiras a se montarem ou vestirem-se "de mulher", muitas vezes eram as mesmas que as prestigiavam nos espetáculos de travestis. Segundo Cláudia Celeste, os espetáculos, nas décadas de 1960 e 1970, tinham um público basicamente feminino e de classes média $e$ alta, principalmente porque o que faziam no palco era certa homenagem a elas: 
A maquiagem feminina, o cabelo, a peruca era ajeitada feminina, tudo era muito feminino; ss roupas femininas, não era coisa muito pejorativa à mulher. Por isso que as mulheres também eram fãs. As mulheres não se sentiam mal, entendeu? Era como se fosse uma homenagem a elas, entendeu? (Cláudia Celeste em entrevista ao autor, em 05 de outubro de 2012).

Capa da edição de número 272 do Jornal $O$ Pasquim com o título "Miss Boneca - Noite Deslumbrante no Carlos Gomes", em 1974 (Figura 8, seguida das Figuras 9 e 10), esse concurso de beleza parece ter gozado de certa credibilidade em determinados círculos sociais ou ao menos gerado bastante curiosidade. Como era de praxe n' $O$ Pasquim, a cobertura do Miss de 1974 seguiu um tom informativo mesclado ao deboche característico do jornal, como se nota no pequeno excerto a seguir:

O clímax foi, é claro, a apresentação de Rogéria.

Houve a escolha de Miss Simpatia pelas concorrentes (ganhou Miss estado do Rio).

Em seguida as misses cantaram o hino, houve lágrimas de emoção incontida e muito rímel escorrendo pelas caras.

Depois o júri deliberou e escolheu a bela loura de Santa Catarina, Paulette Paola, Miss boneca Pop 74. Em segundo lugar, Miss Ceará, Esmeralda Varandas. Aloma, representante da Bahia, que recebeu o voto de Duda Guendes para mulher sexy d'O PASQUIM, ficou em $4^{\circ}$ lugar (Uma noite de deslumbramento..., 1974:03). 


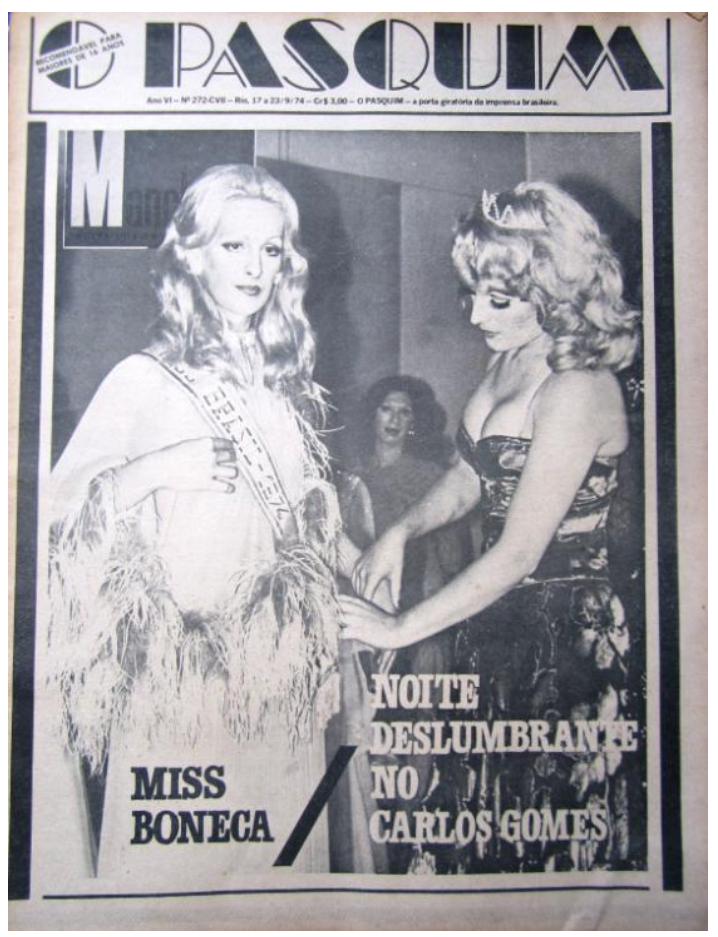

Figura 5 - O Pasquim, edição 272/1974. Acervo do autor. 


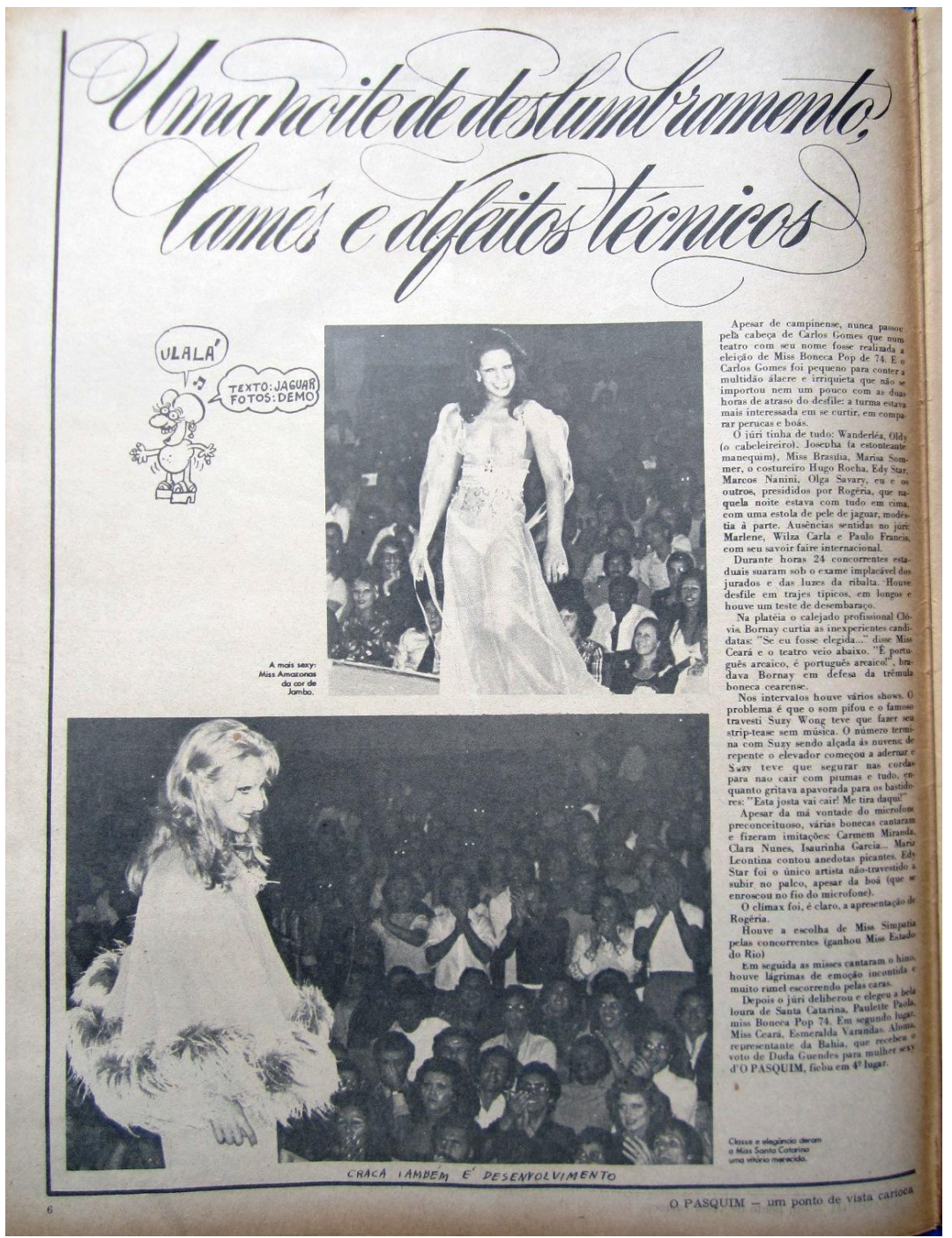

Figura 6 - O Pasquim, edição 272/1974. Acervo do autor. 
cadernos pagu (50), 2017:e175015 Para uma história dos concursos de beleza trans

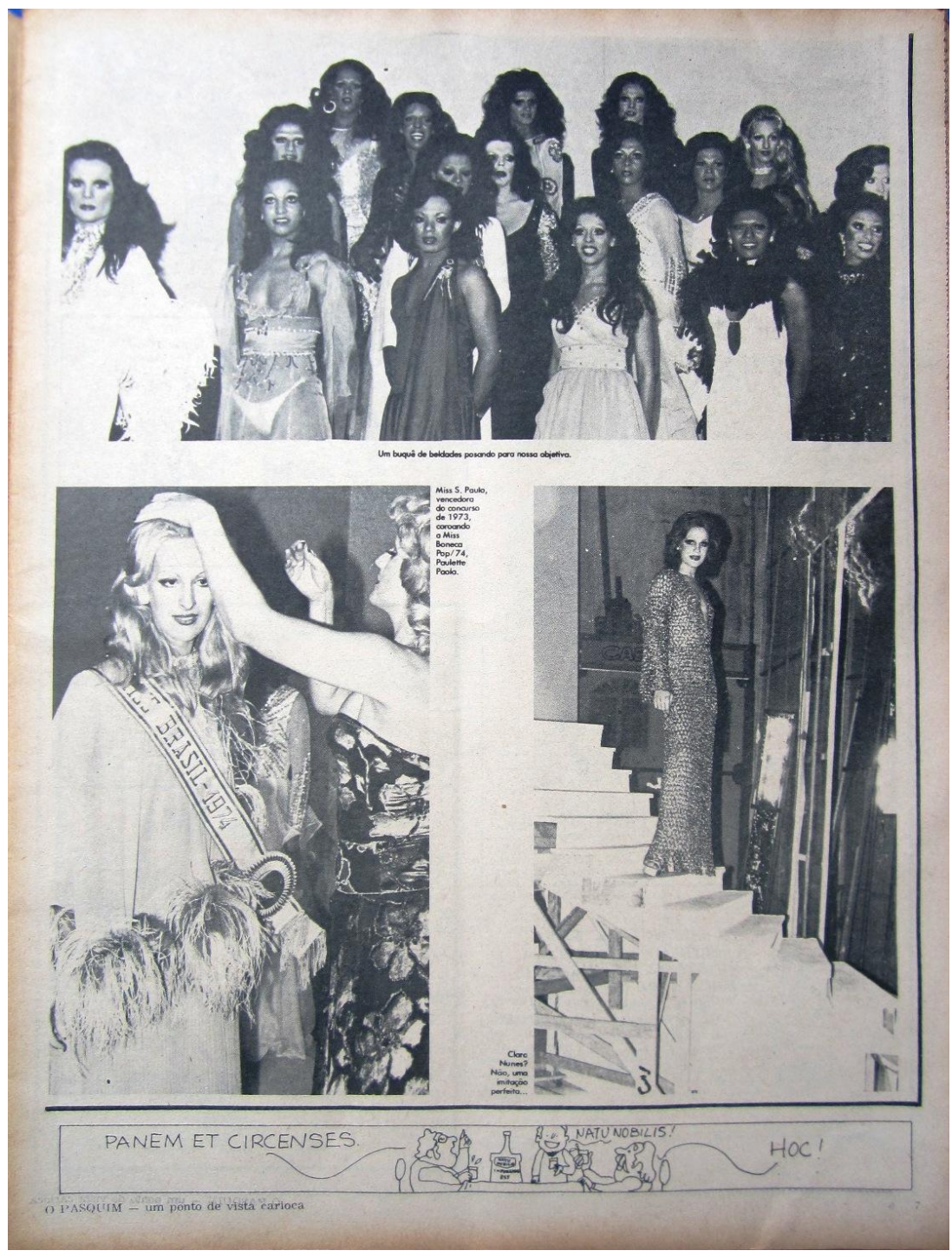

Figura 71 - O Pasquim, edição 272/1974. Acervo do autor. 
A coluna "Linhas Cruzadas" de Scarlet Moon e Nelson Motta, no Jornal O Globo, daquele mesmo ano (1974:31) também deu destaque ao concurso, noticiando, entre outros acontecimentos da noite, a emoção das candidatas, a alegria do público, os shows realizados e algumas falhas técnicas, além de afirmar que

O júri era formado por alegres personalidades como Oldy, o coiffeur, (em noite de despojamento e simplicidade), Rudy (em altos brilhos e peles aproveitando o frio), Marco Nanini (gripado), Jaguar (em jeans), Edy Star (de xale porque sua cobra estava de folga e o boá sumiu), costureiro Hugo Rocha (de tranças, lançando a linha Taras Bulba), Wanderléa (ovacionada ao chegar) e Rogéria (recebida em delírio e emocionando a platéia ao cantar "Carinhoso" em três línguas, inglês-francês-protuguês, principalmente na parte do "Vem, vem, vem, come, viens sentir o meu coeur").

[...] recomeçou o desfile de atrações com Jane numa emocionada interpretação do vanusiano sucesso "Manhãs de Setembro". Ao setembrino som, as doze finalistas voltaram ao palco: eram as que tinham melhor correspondido aos quesitos "elegância", "simpatia" e "traje típico". Orientadas pelo costureiro "Maria Augusta", desfilaram de seis em seis para a parte final do julgamento, que compreendia novos quesitos como "beleza" $e$ "desembaraço oral" a ser provado respondendo, em público, à pergunta: "Se ganhasse o título, o que você nos levaria a conhecer em seu Estado?"

Nervosa, a primeira candidata respondeu: "Se eu fosse elegida..."

O público ameaçou vaiar mas ouviu-se mais forte a voz autoritária de Clóvis Bornay: "Pára, pára que a menina está certa, é português arcaico..." (Moon; Motta, 1974:31, grifos no original). 
Assim como a referida edição do jornal " $O$ Pasquim", a coluna de Nelson Motta e Scarlet Moon também deu bastante espaço para o Miss Boneca Pop (como nomeado pela reportagem), afirmando ainda que aquela noite de "contentamento e finesse" (Moon; Motta, 1974:31) terminou com a coroação da Miss Santa Catarina, Paulette Loramil, como a Miss Boneca Pop ou Miss Brasil. Curioso é o fato de que os autores relataram que a coroa foi entregue à Paulette pela "Rainha de 73", figura e ano que não constam no relato de Cláudia Celeste nem no discurso da organização do Miss T Brasil. Não foi possível saber quem era essa "Rainha de 73" ou que concurso de beleza pode ter sido realizado naquele ano, figurando como oficial no histórico do Miss T Brasil (e talvez do Miss Boneca Pop) a edição de 1974 como pioneira e emblemática para uma história dos "concursos de beleza trans". 

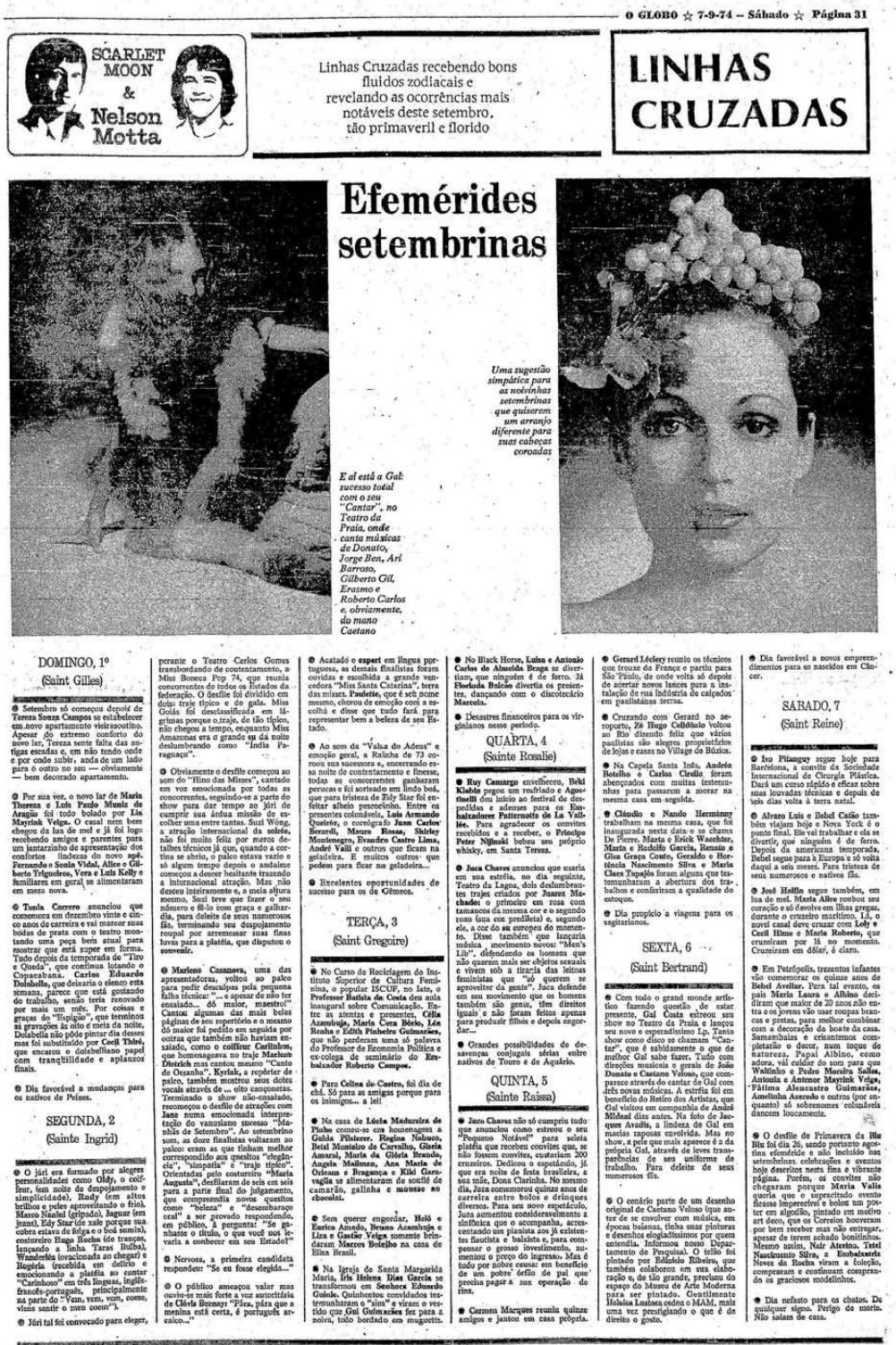

Figura 8 - Coluna Linhas Cruzadas no Jornal O Globo, de 09 de setembro de 1974. Acervo do autor. 
cadernos pagu (50), 2017:e175015 Para uma história dos concursos de beleza trans
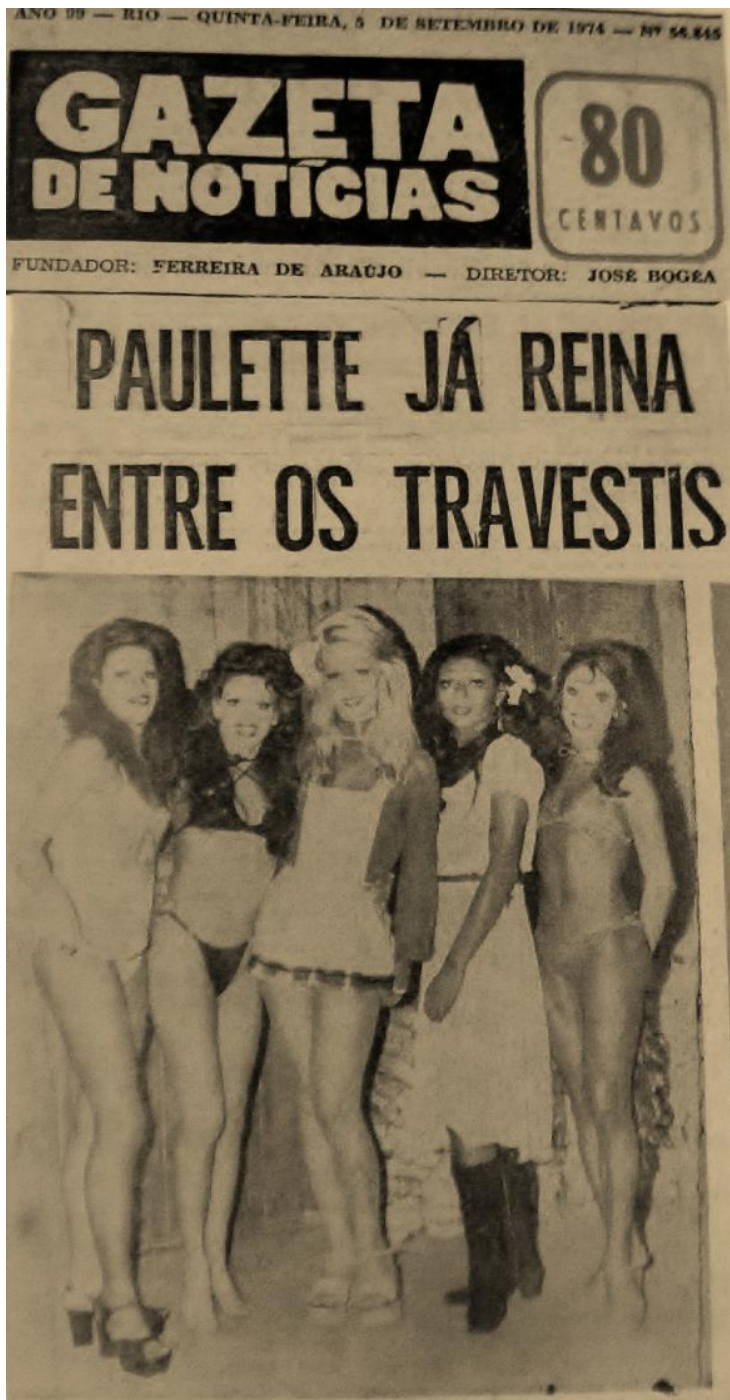

Paulette Paôla, modelo fotogrífico o maquiador profissional, está reirumdo entre os travestis, eleita que fol "Boneca Pop 74". Ela e stras princesas. Fsmeralda, Ctáudia, Aloma e Edna - todas bailarinat, atrip-fente e modelon - partem agora para a eleiçắo de Mis Universo. (Leia maiores detalhes a respeito na terceira pág.)

Figura 9 - Gazeta de Notícias, de 05 de setembro de1974. Acervo pessoal Cláudia Celeste. 
De acordo com o relato de Cláudia, "no segundo ano, vence a Ângela LeClery, que hoje nós conhecemos, cantou o hino nacional e tudo. Era [uma] mulata muito linda, uma morenaça, entendeu? Muito bonita e tudo" (Cláudia Celeste em entrevista ao autor, em 05 de outubro de 2012). Cláudia menciona a vitória de Ângela, mas não dá maiores detalhes por não ter participado porque "nesse ano, eu tava [sic] fazendo alguma coisa em televisão, não sei [que] trabalho que eu tava [sic] fazendo. Trabalho de shows, essas coisas todas" (Cláudia Celeste em entrevista ao autor, em 05 de outubro de 2012).

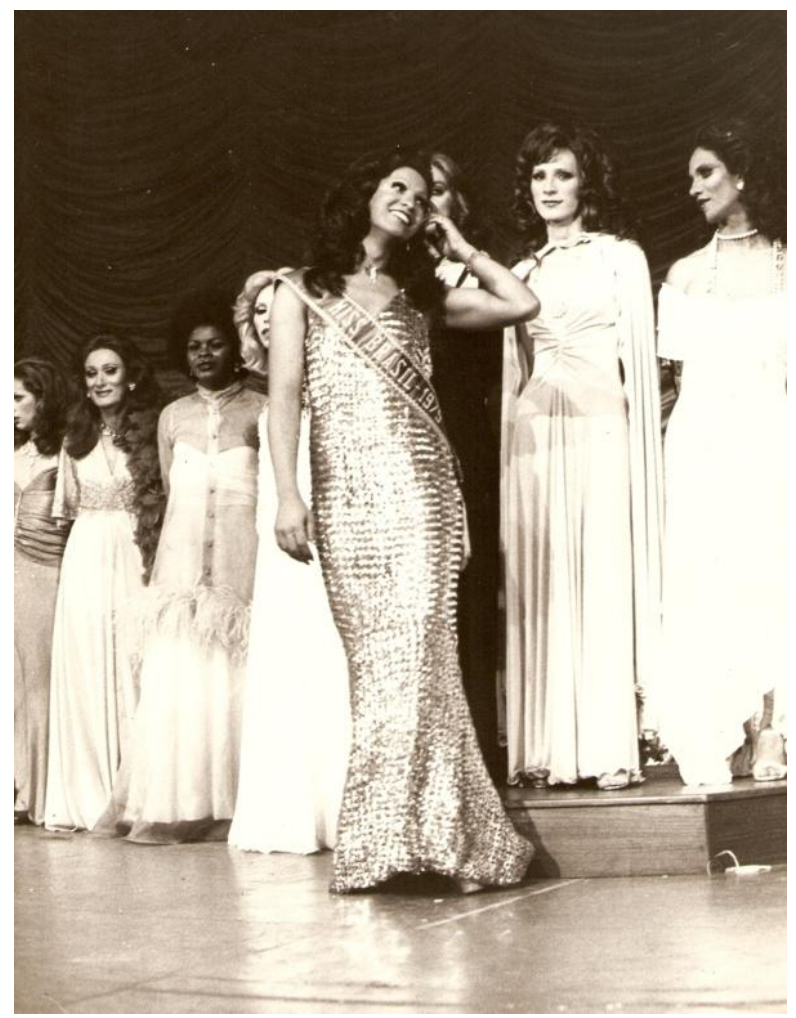

Figura 10 - Ângela LeClery coroada vencedora do Miss Pop 1975. Acervo pessoal Cláudia Celeste. 
A segunda edição do Miss Pop foi também destaque no jornal $O$ Pasquim (edição $\mathrm{n}^{\circ} 318$ ), porém dessa vez com sua tradicional cobertura informativo-humorística um pouco menor que no ano anterior e sem ter o destaque de capa. $\mathrm{O}$ jornal fazia gracejos qualificando aquela "festa que está ameaçando engolir o concurso que lhe serviu de modelo, o de Miss Brasil, que não chega aos pés em matéria de pitoresco e picardia" (Jaguar, 1975:17). Este "pitoresco e picardia" podia ser de certa forma identificado e quantificado segundo algumas características, como a de que "a reportagem anotou que a expressão mais usada na noite foi 'Querida!' (532 vezes) seguida por 'Audáciaaa!' (311 vezes)" (Jaguar, 1975:17).

A matéria de Jaguar em $O$ Pasquim chamava a atenção para a composição do júri daquela noite composto por

3 pesos pesados do folclore carioca: Dercy Gonçalves, cintilante num corpete de paetês azuis, boá roxa e saia de 'voile' amarela transparente, madame Satã, toda de branco com seu legendário chapéu de panamá e um casaco de peles também branco que contrastava deliciosamente com o casaco de peles negro de Clóvis Bornay (Jaguar, 1975:17).

A cobertura seguia à risca aquelas de colunas sociais de revistas de entretenimento $e$ descrevia em detalhes a vestimenta das celebridades acima mencionadas. Não deixa de ser irônico que, ao longo da matéria sobre o Miss Pop 75, o jornal utilize o pronome masculino para se referir às candidatas, todas em sua plena "beleza e esplendor" femininos, ao passo que na menção à Madame Satã, em trajes e performance de gênero masculina, seja usado o pronome feminino.

A noite foi assim resumida por $O$ Pasquim:

\section{Um concurso de Miss sem tirar nem por}

O desfile, realizado debaixo de intensa vibração do público que abarrotava o teatro, seguiu rigorosamente a tradição. Primeiro houve o desfile em trajes típicos, depois em trajes 
de gala $e$ finalmente o ponto alto: todas as candidatas cantando em coro, emocionadíssima, o hino das misses: "Os estados brasileiros se apresentam/nesta festa de beleza e esplendor...". um enorme travesti negro, com uma bengala, fiscalizava severamente as desfilantes, numa imitação convincente de Maria Augusta, da Socila. Nos intervalos vários artistas se apresentaram: Shirley Montenegro, com a voz mais aguda que Dalva de Oliveira (felizmente o guitarrista Jorginho correspondeu à expectativa), Edy Star, bailarino "exótico", Alex Marques, a "caricata", Maria Leopoldina (da boate Zig-Zag). No fim a favorita, Miss Ceará, Ângela LeClery, morena cor de jambo foi eleita a Boneca Pop 75, seguida pelas misses Santa Catarina, Brasília, Amazonas, Goiás e Bahia. Eram 2 e meia da manhã quando a festa terminou. Para a reportagem, que assistira ao desfile anterior, uma dúvida pendia: Miss Ceará, a vencedora, não seria a mesma boneca que obteve no ano passado a terceira colocação, como representante do Amazonas? (Jaguar, 1975). 
cadernos pagu (50), 2017:e175015 Para uma história dos concursos de beleza trans

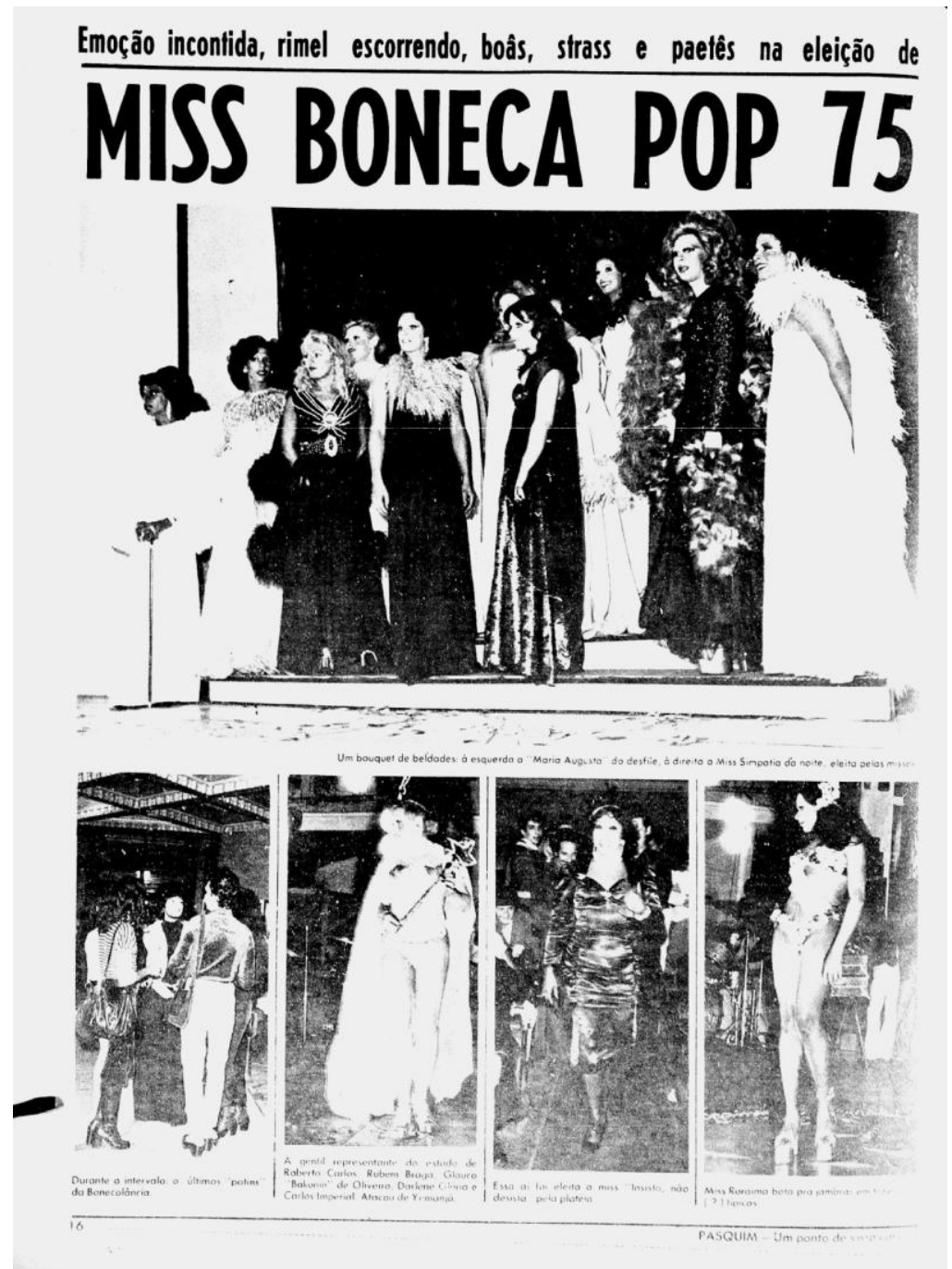

Figura 11 - O Pasquim, edição 318/1975. Acervo Biblioteca Nacional. 


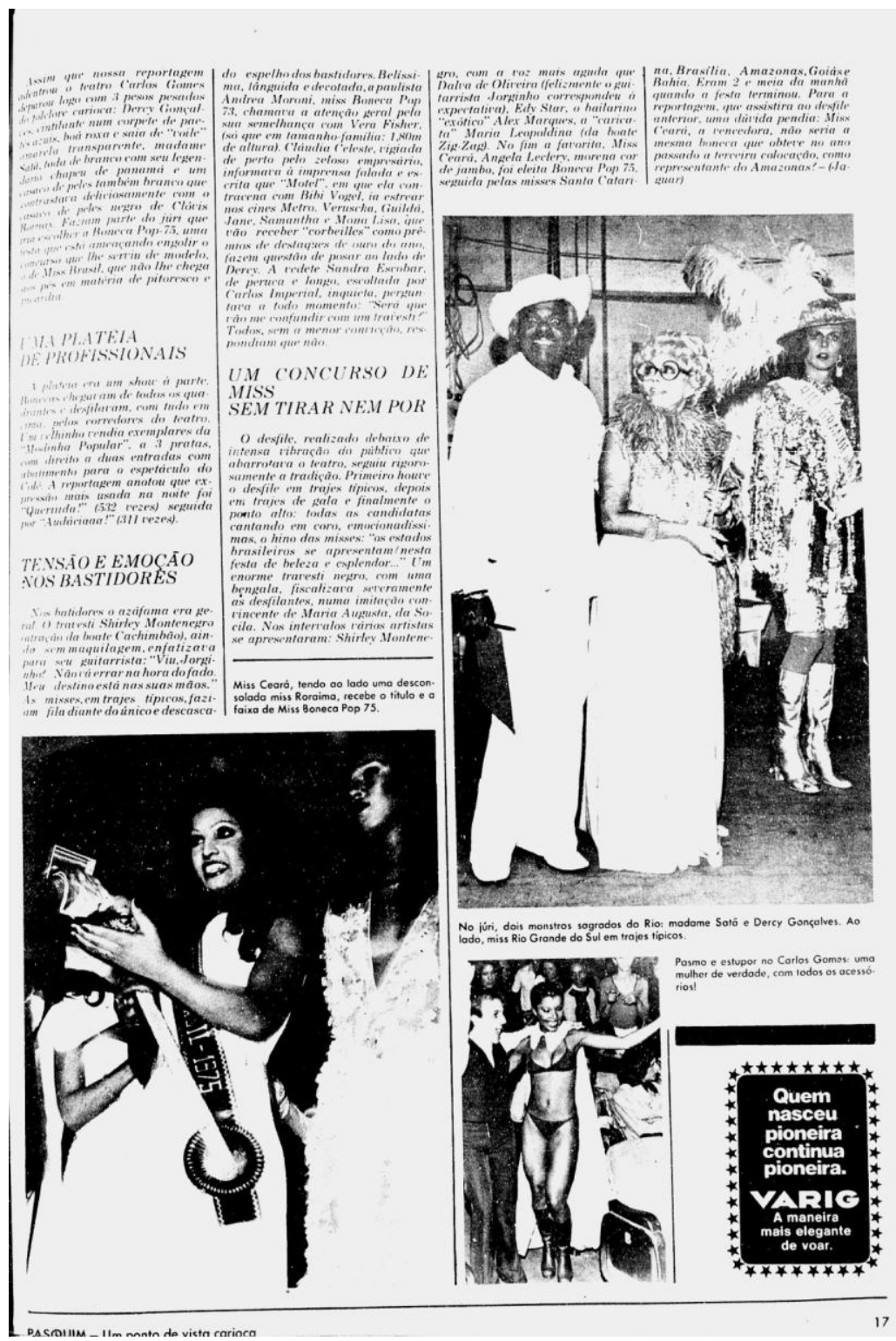

Figura 12 - O Pasquim, edição 318/1975. Acervo Biblioteca Nacional. 
A coroada Miss Pop 75, Ângela LeClery, Miss Ceará naquele ano era sim a Miss Amazonas 1974, caracterização regional muitas vezes apenas simbólica e prática ainda hoje presente em diversos concursos de beleza. Cláudia Celeste foi Miss Rio de Janeiro em 1974 e, em 1976, concorreu como Miss Minas Gerais, tendo sido coroada vencedora:

\section{E como foi a experiência de ganhar o concurso? De ser a vencedora?}

Eu e Aloma éramos fortes candidatas na época. Tinha umas outras lá, umas três ou quatro, que eram fortes candidatas. Mas aquele negócio: "Cláudia, a gente não sabe se você vai ganhar ou não, a gente não pode prometer isso pra ninguém, isso depende da tua hora, da empatia que tem você com as pessoas ali na hora, tudo depende". Por mim tudo bem e a gente aceitava porque a gente queria era folia. Se ganhasse ou não não tinha problema, o problema era participar. A gente queria era tá [sic] no meio do babado. ${ }^{16}$ Porque era uma festa, tudo uma grande festa. Então a gente queria tá [sic] no meio da folia. Então isso que era legal, mesmo que não ganhasse. Foi quando eu ganhei. Comecei a ver que eu ia ganhar quando eu entrei no traje de gala, cabelo deste tamanho, a Suzy Wong era cabeleireira e botou meu cabelo cenoura. Era um vermelho. Naquela época não tinha as cores que tem hoje, era tipo um avermelhado. Cabelo deste tamanho, porque antigamente não usava muito cabelo liso, eriçava o cabelo todo, então ficava aqueles bolos de noiva desse tamanho. Então eu vim com uma cabeleira até aqui assim [fazendo gestos para o alto], magrinha assim, fininha, com um

\footnotetext{
${ }^{16}$ Babado foi um termo bastante presente no contexto do Miss $\mathrm{T}$ Brasil, adjetivando aquilo que tinha sido muito bom ou que merecia algum tipo de destaque, e parece ser recorrente no "universo trans", de modo geral. Segundo definição de Larissa Pelúcio baseada em sua etnografia junto a travestis que se prostituíam em São Paulo, "'babado' pode significar algo muito bom; uma novidade que se conta (geralmente boa); um acontecimento interessante, divertido e/ou com episódios surpreendentes; algo bom. Porém, dependendo do contexto, pode significar algo que vai ter consequências ruins" (Pelúcio, 2013:54).
} 
vestido branco assim de alcinha, todo cravejado de strass $e$ que ele abria assim e um boá de pluma na barra. Quando eu entrei com aquele cabelo, aquela cara, magrinha, cinturinha desse tamaninho, menino o povo veio abaixo (Cláudia Celeste em entrevista ao autor, em 05 de outubro de 2012).

Ao relembrar aquele concurso do ano de 1976 do qual saiu vencedora, Cláudia também discorreu sobre a característica do concurso de ter desfile de gala e traje típico, como nos tradicionais concursos de Miss Brasil ou Miss Universo. Porém, não tinha o desfile de maiô pela impossibilidade de muitas candidatas assim desfilarem, visto que na época não contavam com próteses de silicone ou hormonização, o que, segundo Cláudia, só veio a se tornar popular no fim dos anos 1970. Desse modo, o rosto ganhava todo o destaque e devia mostrar a feminilidade $e$ glamour, como ela bem o fez com o "cabelo bolo de noiva" acima descrito. Já no Miss T Brasil, que se autoproclamava sucessor do Miss Pop, desfiles em biquínis e maiô eram muito valorizados, pois a organização entendia que se o que o público queria era colocar à prova a feminilidade das misses $\mathrm{T}$, elas iam provar que podiam sim desfilar em trajes de banho e, quiçá, ainda melhor do que muitas mulheres (cisgênero). Visando valorizar ainda mais a construção da corporalidade e da feminilidade vistas como belas pelo Miss T Brasil, o desfile em traje típico não foi inserido nesse certame porque, segundo a organização, o dinheiro que seria gasto na confecção de tal traje seria melhor utilizado caso fosse empregado em tratamentos cosmético-estéticos e/ou cirúrgicos.

Assim como no episódio envolvendo a novela Espelho Mágico e a Rede Globo, que involuntariamente colocou uma travesti em uma cena de novela contracenando com a atriz Sônia Braga, Cláudia afirma que sempre foi considerada muito feminina e facilmente confundida com mulher, o que acontece ainda nos dias de hoje. Por isso, podia mostrar um pouco mais seu corpo sem se afastar da figura tradicional de uma miss, como relata a seguir: 
E nos concursos vocês desfilavam em traje de gala...

Traje de gala, traje... maiô não botava, mas por que? Num era travesti, muitos não tinham corpo bonito. Tinha a cara linda, mas o corpo não era lindo, entendeu? Então não usava muito a nudez. Era tudo muito chique, vestidos de gala e traje típico. Então, quem pudesse mostrar corpo, botava no traje típico, entendeu? Por exemplo, eu podia, eu vim com uma malha toda negra assim toda costurada de strass, entendeu? Era uma Catadora de Diamantes (Cláudia Celeste em entrevista ao autor, em 05 de outubro de 2012).

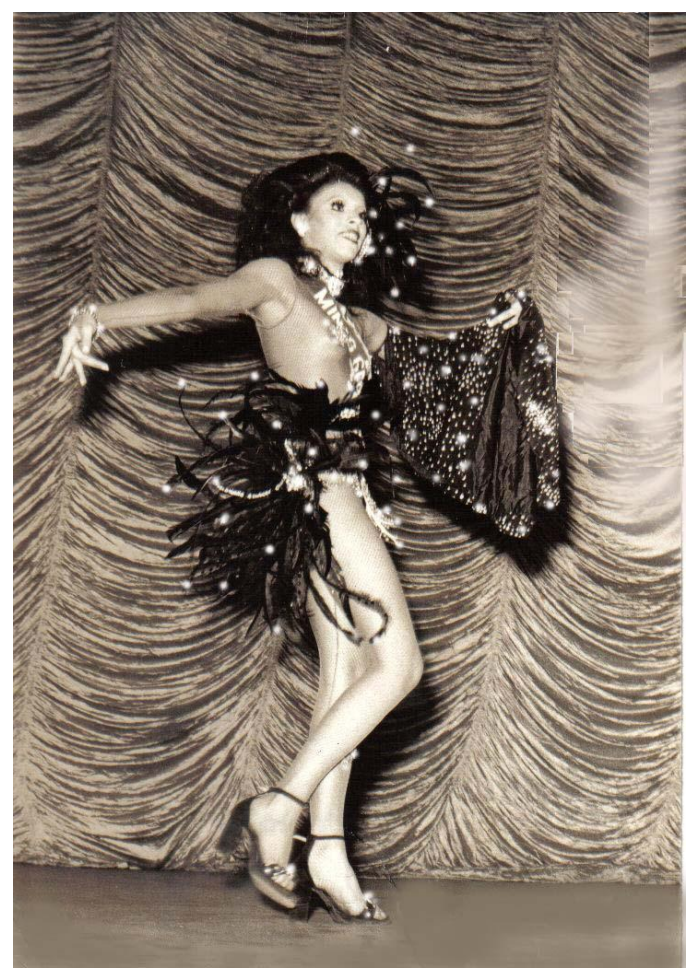

Figura 13 - Miss Pop 1976. Cláudia Celeste como "A catadora de diamantes". Acervo pessoal Cláudia Celeste. 
Montada com aquele cabelão e elegantemente mostrando sua feminilidade como uma "catadora de diamantes" mineira, Cláudia foi então coroada Miss Pop 1976! Apesar de ter "botado a plateia abaixo" em sua entrada, sua coroação não foi tão simples assim, como relembra:

[...] o meu foi em 1976, né, foi quando eu vim por Miss Minas Gerais [...] eu tirei o primeiro lugar. Ganhei o primeiro lugar, em segundo lugar ganhou a Aloma, de São Paulo [...]. Em terceiro lugar, não lembro quem era. Em quarto lugar, Gungala. Gungala que teve até um quiprocó porque a plateia ficou louca porque ela tirou em quarto lugar, entendeu? Não queriam que ela tirasse quarto lugar, as fãs e tudo, aquela coisa toda, queriam... eles estavam esperando que eu ganhasse. Tava [sic] todo mundo esperando que eu ganhasse porque eu tava [sic] realmente, foi meu ano aquele ano. Mas quando a Gungala tirou o quarto lugar, o povo, meu filho, começou a jogar lata de cerveja. Foi um problema que eu tive que ser coroada com a cortina fechada. Ninguém nem sabe quem ganhou, nem escutaram o resultado.

\section{Porque na hora do quarto...}

Não deixaram, no quarto já acabou. Ninguém sabe quem tirou em terceiro, quem tirou em segundo, muito menos o primeiro [risos]. A gente teve que sair, todos os organizadores e eu inclusive, no carro do corpo de bombeiros, pra você ver [risos] o tamanho do tumulto que foi. Esse foi o terceiro ano. Mas não foi por isso que o concurso terminou. $\mathrm{O}$ concurso terminou porque nós estávamos na época dos militares, entendeu? E os organizadores tinham sempre um problema, entendeu? (Cláudia Celeste em entrevista ao autor, em 05 de outubro de 2012).

Gungala contava com uma plateia fervorosa que não aceitou sua colocação fora do Top 3. Cláudia conta que assim que entrou no palco viu-se como favorita e até a torcida de Gungala 
reconhecia seu favoritismo. Porém, só não concordaram com seu quarto lugar, o que consideravam injusto para aquela bela travesti da Lapa. Em seu relato, Cláudia Celeste reconhece a beleza de Gungala, mas afirma que ela perdeu ponto com os jurados porque não tinha aprendido nem seguia à risca "uma postura de Miss, de concurso de Miss. E a Gungala exatamente na hora que desfilou ela jogou o cabelo e fez [desfilando e fazendo gestos de certo exagero]. Perdeu ponto. Ainda deram o quarto lugar" (Cláudia Celeste em entrevista ao autor, em 05 de outubro de 2012). Mesmo que com tons pitorescos e de picardia, como qualificado pelo jornal O Pasquim em 1975, ou como uma grande festa da qual importava participar para estar "no meio do babado", uma miss é uma miss e deveria sim ter postura, elegância, simpatia e outros predicados tão apregoados pelo Miss Brasil e sua grande parceira nesse mundo de beleza e elegância, a escola Socila. ${ }^{17}$

Recortes estratégicos da memória e produção da "cultura trans"

A primeira edição do Miss Boneca Pop $e$ as duas subsequentes narradas acima são tidas como "históricas" na linhagem do Miss T Brasil. Paulette Loramil (referida como Paulette Paola nas mencionadas reportagens) foi a vencedora do ano de 1974, Ângela LeClery em 1975, e Cláudia Celeste ficou com a coroa e a faixa de 1976. Como a última a ser eleita no concurso Miss Boneca Pop, então visto como uma espécie de ancestral do Miss T, Cláudia também passou sua coroa à vencedora da primeira edição da nova competição no ano de 2012. Cláudia Celeste ainda afirmou não ter passado o título à época de sua coroação, pois em 1977 estava na Europa ou envolvida com gravações de TV no Brasil (não se lembrava exatamente), o que vai de encontro ao "discurso nativo" do Miss

\footnotetext{
${ }^{17}$ Socila foi inicialmente uma escola de modelos e etiqueta para mulheres, geralmente da alta sociedade carioca. Fundada em 1953, a "Sociedade Civil de Intercâmbio Literário e Artístico", título resumido na sigla Socila, também ganhou grande notoriedade porque "treinou as candidatas ao título de Miss Brasil, de 1958 até 1976" (Lima, 2009).
} 
$\mathrm{T}$, que circunscreve sua tradição exclusivamente àquelas três primeiras edições.

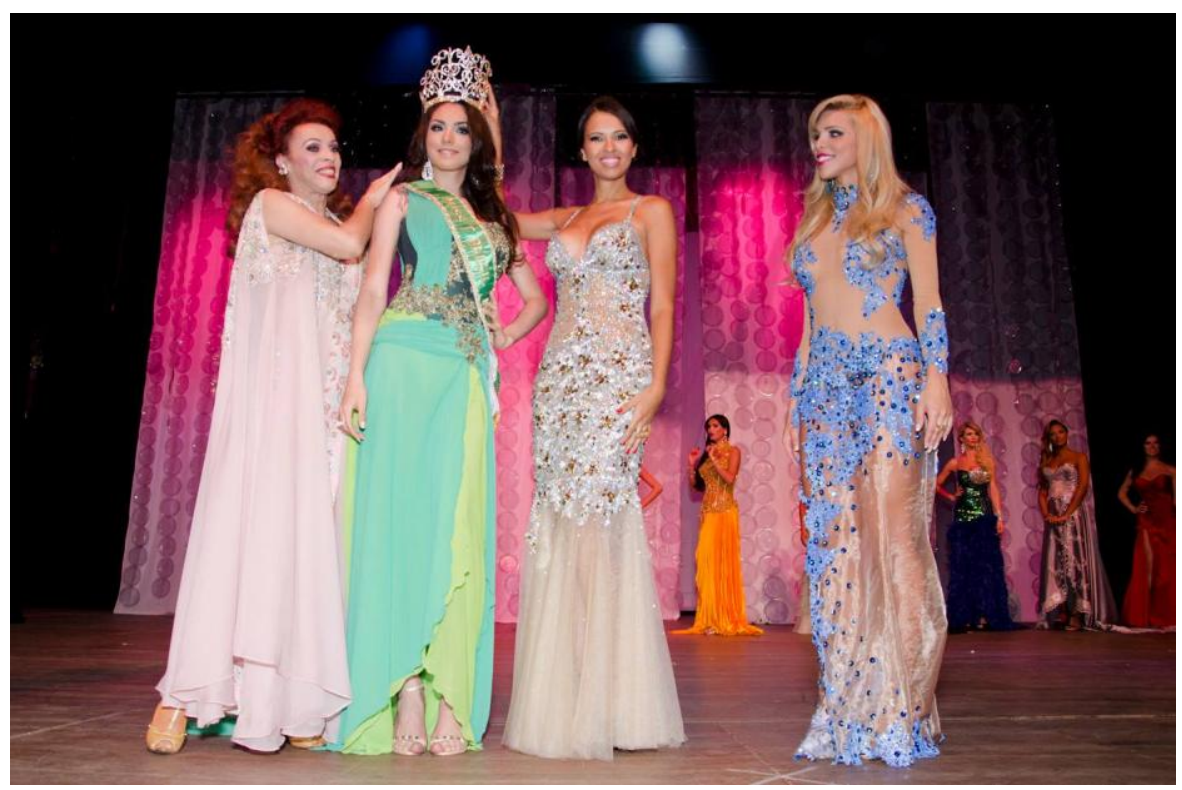

Figura 14 - Cláudia Celeste após passar a coroa para Marcela Ohio, em pose com Ariadna Arantes (uma das apresentadoras do Miss T Brasil 2012) e Roberta Holanda, segunda colocada nesta primeira edição do Miss T. Foto: Aline Macedo para divulgação Miss $\mathrm{T}$ Brasil [https://www.facebook.com/photo.php?fbid =3883797576321\&set=a.38815407 59902.139729.1320327653\&type $=3 \&$ theater - acesso em: 16 ago 2017].

Há aqui um hiato temporal não coberto pelo "discurso nativo" do Miss T, mas sim por Cláudia Celeste ao afirmar que, após o Miss Pop, teve início o concurso de beleza Miss Brasil Gay, no ano de 1977, na cidade de Juiz de Fora. Cláudia faz uma conexão entre os dois concursos da década de 1970 e, de acordo com seu relato, não passou sua coroa apenas por não poder estar presente no concurso de 1977. Se no relato de Cláudia essa conexão se torna possível, em 2012 ela é radicalmente negada pelo Miss $\mathrm{T}$ Brasil, que se concebe como um concurso para 
travestis e mulheres transexuais, palco no qual transformistas ou pessoas que demonstram qualquer trânsito não fixo de gênero não poderia pisar. Segundo "discurso nativo" do Miss T em relação à assunção de uma identidade trans no cotidiano, um tipo de concurso era "sério", o outro era "viadagem".

Cláudia Celeste, ao ser perguntada sobre quem competia naqueles certames da década de 1970, afirmou que

Era tudo misturado. Não tinha este negócio de travesti, transformista não. Todas se candidatavam, desfilavam. [...] A maioria tudo era transformista, eu era uma das poucas que eram, que era trans.

\section{Mas as pessoas usavam este nome, transformista?}

Não, usavam travesti. Travesti para os que tinham peito $e$ transformista para os que não tinham peito, que se vestiam... eram rapazes e só se vestiam de mulher quando se produziam. Tudo para o espetáculo ou para os certames ou alguma coisa assim. Todas tinham suas profissões, todas eram cabeleireiros ou maquiadores ou trabalhavam na casa de não sei de quem. Ou trabalhavam em casas de tecidos, eram vendedores em casas de tecido. Ou trabalhavam como figurinistas, era um negócio assim (Cláudia Celeste em entrevista ao autor, em 05 de outubro de 2012).

O Miss Brasil Gay, referido por Cláudia como a continuidade do Miss Boneca Pop, começou como uma festa promovida por Chiquinho Mota - transformista cujo nome artístico é Mademoiselle Debrette de Leblanc - para ajudar a arrecadar fundos para a Escola de Samba Juventude Imperial, de Juiz de Fora. Segundo informações do website Zona Pink, de Juiz de Fora,

Nas três primeiras edições, o concurso tinha uma conotação carnavalesca misturada ao transformismo. As pessoas não torciam para a representante de um determinado estado, até porque as concorrentes eram todas de Juiz de Fora. Torciam para o destaque da sua escola de samba, fosse 
Juventude Imperial, Real Grandeza ou outra. A partir da década de 80, foram criadas regras para o concurso. Travestis ou pessoas siliconizadas, por exemplo, não podem se inscrever (Zona Pink, 2013).

Até poucos anos atrás, o evento era bastante tradicional na cidade de Juiz de Fora e gozava de projeção nacional, reunindo alguns milhares de pessoas em suas edições anuais. ${ }^{18} \mathrm{~A}$ regra mencionada acima, e definida nos anos 1980, oficializou esse concurso como exclusivamente para transformistas, vetando-o para travestis e mulheres transexuais, ao menos para aquelas cujos corpos não se encontravam de acordo com alguns itens do regulamento. A $35^{\mathrm{a}}$ edição do concurso Miss Brasil Gay, anunciada para o ano 2010 e cancelada poucas semanas antes da data marcada para o espetáculo, previa, por exemplo, no item 3 de seu regulamento, "Pré-requisitos para a inscrição", que o candidato deveria "c) Ser do sexo masculino; d) Ter no mínimo 18 anos completos e no máximo 35 anos; e) Não ter implante de silicone em qualquer parte do corpo;" (2010:3), o que privilegiava a construção de corpos transformistas e a priori excluía a participação de travestis e mulheres transexuais.

Oficialmente gay e transformista, o Miss Brasil Gay, com diversas etapas regionais a ele relacionadas, não permitia a participação de travestis e mulheres transexuais em seu palco para a competição, de modo que elas foram então construindo e/ou participando de uma série de outros concursos e eventos nos quais se sentiam contempladas, como bailes e eleições relacionados ao carnaval. Diversos concursos para travestis e mulheres transexuais também ocorrem em todo o Brasil e no exterior, porém sem relação com o Miss T. O Miss T Brasil reivindicava para si o lugar do concurso nacional para a "população trans" e uma história de

\footnotetext{
${ }^{18}$ Não obtive informações que confirmassem, mas tudo indica que esse concurso deixou de ser realizado, se não completamente, ao menos na cidade de Juiz de Fora.
} 
glória na década de 1970, a qual atualmente se vê honrando e lhe serve como fonte de inspiração.

Mais do que pensar se as participantes desses diferentes concursos eram "verdadeiramente" trans ou não, o que parece ser o ponto chave aqui é o discurso público que se faz sobre tais eventos e manifestações artístico-culturais. Em seu início e durante as primeiras décadas de sua realização, o Miss Brasil Gay não fazia diferenciação entre transformistas e travestis/mulheres transexuais. Porém, com o passar dos anos, suas regras foram excluindo pessoas que tivessem próteses de silicone, entendidas aqui como o grande marco da passagem de um masculino transformista para um feminino transexual e/ou travesti. Essa separação entre transformistas e travestis/mulheres transexuais no universo dos concursos de beleza parece se inserir em um processo mais amplo e histórico de diferenciação entre tais categorias identitárias e afirmação política de uma identidade coletiva trans (travesti e transexual). Segundo Mário Carvalho e Sérgio Carrara (2013:234),
as travestis só surgem como sujeito político a ser incorporado pelo então movimento homossexual quando a opção por uma política identitária começa a se consolidar e as categorias abarcadas pelo movimento passam a ser especificadas,

processo que teria se iniciado na década de 1970, se consolidado nos anos seguintes e que, no início dos anos 1990, institucionalizaria uma militância e política identitária "trans" com a criação de associações voltadas especificamente para travestis, como a Associação das Travestis e Liberados do Rio de Janeiro (ASTRAL) $^{19}$ (Carvalho; Carrara, 2013). E em todo esse processo de

\footnotetext{
${ }^{19}$ A ASTRAL é tida por lideranças trans como a primeira organização política voltada para esse coletivo no Brasil e na América Latina, ainda que iniciativas anteriores já se fizessem presente, como a Casa de Apoio Brenda Lee, criada por travesti de mesmo nome em 1984, para receber pessoas soropositivas e/ou vítimas de violência (em sua maioria travestis) na cidade de São Paulo. Porém,
} 
construção e afirmação de um sujeito coletivo "trans", transformistas e homossexuais afeminados em trajes femininos se configurariam como o outro constitutivo deste sujeito político.

Trabalhos clássicos como o de Hélio Silva (1993), Don Kulick (2008) e, em menor grau, o de Marcos Benedetti (2005) também apresentam a diferenciação entre transformistas $e$ travestis, principalmente a partir das falas e concepções de travestis de que transformistas seriam uma espécie de "fraude" (Kulick, 2008:83) por não modificarem seus corpos de forma vista como "definitiva" e não viverem "como mulher 24 horas por dia" (Kulick, 2008:83). Nessa diferenciação, transformista poderia ganhar ares de categoria acusatória na conformação de uma identidade e visibilidade pública dita trans, como afirma Mário Carvalho (2011) e como esteve presente tanto no discurso público como nos bastidores do Miss T Brasil. ${ }^{20}$ Nesse sentido - e diferente da miscelânea e/ou imprecisão identitária do Miss Brasil Gay dos primeiros anos -, o Miss $\mathrm{T}$ tentou encarnar-se como exclusivamente trans. Toda complexidade e diversidade que poderiam estar envolvidas em ambientes nos quais virtualmente diversas nuances do feminino teriam possibilidade de estar presentes dissolvem-se quando um discurso político público precisa ser afirmado como "a cara" do evento. E, sob a rubrica da eleição da "mais bela trans do Brasil", o Miss T voltou-se exclusivamente para candidatas travestis e mulheres transexuais $e$ para a sua visibilidade pública como seu grande projeto político.

Além disso, é importante frisar que, apesar de diversas parcerias, a insistência de Majorie Marchi, organizadora do Miss T, foi por aquilo que nomeava como "uma metodologia

de acordo com Carvalho e Carrara (2013:325), "essa iniciativa, que poderíamos caracterizar como de cunho comunitário e de mútuo apoio, parece não ser diretamente responsável pelo surgimento das primeiras organizações políticas de travestis e transexuais".

${ }^{20}$ Não entrarei na discussão sobre uma diferenciação entre as categorias travesti e transexual por não haver disputa entre elas em meu campo. Para essa discussão, ver Barbosa (2010; 2015), Leite Junior (2008), Carvalho (2011), entre outros. 
TransPower", para todas as ações e eventos da ASTRA-Rio, de modo que sejam, segundo suas palavras,

totalmente criados e dirigidos e executados por nós [...] e acredito muito, pois [...] temos como normativa contratar Travestis e Mulheres transexuais mesmo que não sejam exímias profissionais nas respectivas áreas, pois geramos empoderamento e temos, como é tradição, eventos e ações personalizadas (Marchi, 2012).

Parece que termos como "empoderamento", "tradição" e "eventos e ações personalizadas" possam aqui ser entendidos como um modo de realização de ações que seja concebido $e$ experienciado como próprio, como algo que não está sob a tutela de nenhum outro grupo e que, justamente por isso, pode ser construído da forma como um "nós" deseja e reconhece como importante e legítimo para si. E talvez ao serem alocados na noção de uma manifestação artístico-cultural, tais termos e ações se transformem na autoproclamada "cultura trans" tanto por uma simples ação semântica como também pelo conteúdo que trazem $e$ que é reconhecido como importante e porventura parte constituinte desse coletivo.

A história e a tradição acima narradas foram então criadas pelo "discurso nativo" do Miss T Brasil como "cultura trans". Juntamente com outros eventos realizados anteriormente ao Miss T Brasil - como o "Concurso Rainha Beleza Praiana", realizado pela ASTRA-Rio em 2010 na Praia de Copacabana -, os concursos de beleza seriam parte fundamental do que esse grupo ou "população trans" construía como cultura para si e para a sociedade mais ampla, principalmente por ser espaço de exercício $e$ visibilidade de tópicas que diriam diretamente de uma estética feminina tão cara a tal "população". Talvez o Miss T Brasil, especialmente por sua apropriação do Miss Boneca Pop $e$ construção de memórias coletivas ditas trans, possa ser visto como um exemplo encarnado daquilo que Bruno Barbosa (2015) chamou de "culturalismo travesti": a construção de uma 
identidade travesti quase étnica que precisaria ser "preservada" $e$ publicizada com orgulho, visto ser algo do campo da "tradição" $e$ da cultura brasileira (Barbosa, 2015). Mesmo que o Miss T tenha se enunciado de forma genérica como "cultura trans" e a ideia de um "culturalismo travesti" venha para salvaguardar prioritariamente a identidade travesti, penso que as duas noções se unem $(e$, em um certo sentido, se sobrepõem) em seus objetivos e na efetiva produção de uma identidade trans pública que não se coloca sob a tutela do campo biomédico nem pretende dissolver-se na categoria "mulheres" (cisgênero). O que estava em pauta no Miss $\mathrm{T}$ era a afirmação de uma identidade feminina trans que tanto celebrava uma identidade travesti ( $e$ tudo aquilo que poderia ser visto como característico de tal identidade) como não excluía de seu escopo discursivo aquelas que se concebiam como mulheres transexuais.

Cabe ressaltar ainda que essa noção de "cultura trans" marcada pela criação de memórias e tradição e dotada de um componente de orgulho e empoderamento/"transpower" foi corroborada e legitimada tanto pelo lugar político ocupado por Majorie Marchi como pela parceria com o Programa Rio Sem Homofobia na realização do concurso. Majorie Marchi foi a idealizadora, organizadora, apresentadora e a "mãezona das misses", como foi nomeada em uma entrevista ao Portal Cata o Babado (2014), do projeto Miss T Brasil. Em entrevista para a Agência Fiocruz de Notícias no ano de 2007, Majorie Marchi se apresentava como "brasileira, nascida no estado do Rio de Janeiro em 13 de dezembro de 1974. Tenho ensino médio completo [...]. Sou travesti desde os 13 anos. Sobrevivi da prostituição dentro e fora do Brasil (Itália, Suíça, França)". Nessa entrevista, ela ainda destacava sua participação como "aluna" do Projeto Damas em 2003 e, após a conclusão de sua participação em tal projeto e ter sido empregada em outros locais, teve a "oportunidade de coordenar a execução do mesmo projeto que mudou a minha vida, possibilitando a outras 'trans' terem a mesma oportunidade" (Marques, 2007). 
Concomitante à sua presença no Projeto Damas, em 2005 Majorie foi, juntamente com Hannah Suzart, militante travesti do estado do Rio de Janeiro falecida em 2006, uma das fundadoras da ONG Associação das Travestis e Transexuais do Estado do Rio de Janeiro (ASTRA-Rio). Com a morte de Hanna Suzart, Majorie passou a ter maior destaque no movimento de travestis $e$ transexuais (Carvalho, 2011). Segundo descrição em seu blog que esteve ativo entre outubro de 2009 e maio de 2012, a ASTRA-Rio elencava como seus principais interesses e objetivos: "representar os segmentos de Travestis e Transexuais do RJ, política $e$ socialmente"; "associar, mobilizar e capacitar Travestis $e$ Transexuais do estado do RJ, a fim de formar uma consciência cidadã"; "propor, avaliar e monitorar políticas públicas afirmativas focadas neste segmento"; "divulgar as temáticas Travestilidade $e$ Transexualidade"; "acolher, demandas e denúncias do público alvo, encaminhando e monitorando seu desdobramento" (ASTRARio, 2015). ${ }^{21}$

Em certo sentido, falar de Majorie Marchi é falar da ASTRARio e vice-versa, pois esse foi seu grande projeto político, e ela foi, por bastante tempo, o grande nome da instituição. E, após sua saída do circuito da prostituição em meados de 2003, sua atuação, sua figura pública e sua visibilidade foram construídas durante anos junto ao movimento social de travestis e transexuais, trajetória que de diversas formas possibilitaria quase uma década depois a realização do Miss T Brasil, em 2012.

No período de 2009-2011, Majorie foi vice-presidente da Articulação Nacional de Travesti e Transexuais (ANTRA), além de ter ocupado a vice-presidência do Conselho Estadual LGBT do Estado do Rio de Janeiro. No ano de 2009, através da ASTRA-Rio, foi a organizadora do Encontro Nacional de Travestis $e$ Transexuais (ENTLAIDS) $)^{22}$, principal espaço de articulação

\footnotetext{
${ }^{21}$ Ver: http://astra-rio.blogspot.com.br/

${ }^{22}$ Em sua dissertação de mestrado, Mário Carvalho (2011) traça um histórico destes encontros e afirma que o primeiro encontro de travestis e transexuais nesses moldes aconteceu na cidade do Rio de Janeiro, em 1992, sob o nome "Encontro Nacional de Travestis e Liberados", organizado pela ASTRAL. Mário
} 
nacional para travestis e transexuais. Esse encontro de 2009 teve como slogan "Muito prazer, eu existo!", marca direta da importância da visibilidade para este coletivo. Isso é destacado por Keila Simpson, reconhecida liderança travesti nacional, ao afirmar que tais momentos eram importantes

porque sempre no último dia, a gente fazia uma manifestação ou uma passeata pelas ruas de onde o encontro era sediado ou um ato público em algum monumento público, em alguma praça; para que a gente demarcasse naquela cidade que a gente estava ali e que estava reagindo (citada por Carvalho, 2011).

Desde o ano de 2011 até sua morte em abril de 2016, Majorie integrava a equipe do Programa Estadual Rio Sem Homofobia, da SUPERDir/SEASDH, no qual inicialmente foi uma das coordenadoras dos Centros de Cidadania LGBT alocadas na sede da SUPERDir/SEASDH - chamados Centros de Referência LGBT à época. Posteriormente, no início de 2014, assumiria a Coordenação do Centro de Cidadania LGBT Leste, na cidade de Niterói. Apesar do notável protagonismo de Majorie Marchi e da ASTRA-Rio na criação do Miss T Brasil, podemos afirmar que as quatro edições (2012-2015) realizadas sob sua liderança só puderam ocorrer pelo apoio e patrocínio do programa estadual Rio Sem Homofobia da SUPERDir/SEASDH. Se a ASTRA-Rio foi a protagonista na idealização e na organização do evento, sua execução foi possibilitada pela parceria e apoio do Rio Sem Homofobia. Dada a inserção de Majorie Marchi junto a tal programa e o espaço que era ali dedicado às chamadas "questóes

Carvalho (2011) observa que o termo "Liberados" fazia referência à "gays, lésbicas e pessoas simpatizantes". A partir de 1996, tais encontros anuais passaram a ter financiamento do Ministério da Saúde através do Programa Nacional de DST-Aids, de modo que passou a se chamar ENTLAIDS, Encontro Nacional de Travestis na Luta contra a Aids. Posteriormente o nome do evento passou a ser Encontro Nacional de Travestis e Transexuais, porém a sigla, já conhecida, foi mantida (Carvalho, 2011). 
trans", essa parceria foi possível e acabou sendo a responsável pela quase totalidade do financiamento do certame nessas quatro primeiras edições. ${ }^{23}$

O programa estadual Rio Sem Homofobia nomeia-se como uma política que

visa combater a discriminação $e$ a violência contra LGBT $e$ promover a cidadania desta população em todo território fluminense, respeitando as especificidades desses grupos populacionais, [suas ações são executadas] através de disseminação de informações sobre direitos e sua defesa [...] além da produção, implementação e monitoramento de políticas públicas transversais, isto é, em todas as áreas de governo, a fim de promover a cidadania LGBT (Rio Sem Homofobia, 2015).

É notório que o grande mote da SUPERDir/SEASDH é o propagado "combate à homofobia e promoção da cidadania LGBT" a partir da estrutura administrativa do estado do Rio de Janeiro, posição de onde apoiariam regularmente o Miss T Brasil e outros eventos, como a Parada do Orgulho LGBT do Rio de Janeiro. Isso não só garantiu que todas as candidatas tivessem hospedagem em hotel na cidade do Rio de Janeiro e o espetáculo pudesse ser realizado com a estrutura que um concurso de beleza pede, mas também conferiu legitimidade ao concurso - $e$, consequentemente, às travestis e mulheres transexuais - frente ao "governo do estado do Rio de Janeiro", como foi frisado em diversos momentos pelo superintendente estadual de Direitos Coletivos, Individuais $e$ Difusos, Cláudio Nascimento.

Nomear-se como "o governo do estado" no reconhecimento desse evento e de sua "população-alvo (trans)", parece criar um "efeito de Estado", segundo a noção de Mitchell (2006), para quem "o fenômeno que denominamos 'o Estado' surge de

${ }^{23}$ Após a morte de Majorie Marchi, o Miss T Brasil se desligou do Programa Rio Sem Homofobia e passou a ser organizado pela equipe que a acompanhou naqueles anos, incluindo diversas ex-participantes. 
técnicas que permitem que práticas materiais mundanas assumam o aspecto de uma forma abstrata, não material" (2006:170). ${ }^{24} \mathrm{~A}$ nomeação do Programa Rio Sem Homofobia como o "governo do estado", que tanto patrocinava o concurso como ofereceria serviços voltados às demandas da "população trans" 25 , parecia criar esse enquadre de uma ideia de Estado que acaba por envolver o Miss T Brasil nas dimensões de discurso político e da materialidade efetiva do espetáculo no palco.

$\mathrm{O}$ que parecia dar o tom da parceria entre esse ente do "governo do estado" e um concurso de beleza era a legitimação do discurso público do Miss T Brasil: se o Miss T Brasil apregoava a "beleza em prol da cidadania" (em 2012), "a beleza contra a transfobia" (em 2013) e "pelo direito de ser quem somos" (em 2014), a ideia de um órgão da administração do estado que também luta contra a mesma ou correlatas formas de violência é mais do que bem-vinda na construção de um discurso político e imagem pública para o certame, ainda mais porque aquele órgão também pretende promover "a cidadania LGBT", guarda-chuva que, naquele contexto, poderia abarcar a cidadania trans, apoiando e legitimando o discurso do Miss T.

Os órgãos públicos/governamentais e do movimento social, respectivamente, Rio Sem Homofobia/SUPERDir/SEASDH e

\footnotetext{
${ }^{24}$ Tradução livre, no original: "the phenomenon we name 'the state' arises from techniques that enable mundane material practices to take on the appearance of an abstract, nonmaterial form" (Mitchell, 2006:170).

${ }^{25}$ A grande pauta da retificação do nome e sexo nos documentos oficiais de identificação para travestis e transexuais talvez fosse a ação mais concreta que o Programa Rio Sem Homofobia e seus serviços poderiam "oferecer" ao coletivo deste certame, já que, apesar de não poderem efetivamente modificar tal status, poderiam acompanhá-las pelos caminhos administrativo-burocrático que deveriam percorrer para tal fim. Além disso, contavam com parcerias com órgãos mais competentes para tal questão, como Núcleo de Defesa da Diversidade Sexual e Direitos Homoafetivos, NUDIVERSIS, da Defensoria Pública Geral do Estado do Rio de Janeiro, DPGE/RJ, analisado por Lucas Freire (2015) justamente em sua atuação na retificação de nome e sexo de travestis $e$ transexuais.
} 
ASTRA-Rio, davam a chancela institucional necessária para que o Miss T Brasil se justificasse como aquele

\begin{abstract}
projeto [que] tem como objetivo visibilizar positivamente travestis e mulheres transexuais brasileiras, sua identidade, cultura, pleitos e especificidades sociais através de atividade cultural transversal que dialogue com outras temáticas como direitos humanos, saúde e promoção da cidadania trans,
\end{abstract}

conforme foi dito por Majorie Marchi no palco da segunda edição do Miss T Brasil, em 2013. Tais instituições pareciam garantir certa politização e legitimidade ao concurso de beleza Miss T Brasil e, consequentemente, à sua noção de "cultura trans", a qual também ajudavam a produzir. E apesar de reiterar que tal "cultura trans" possa se integrar à noção de "culturalismo travesti" (Barbosa, 2015), cabe ressaltar que, no contexto do Miss T Brasil, a "cultura trans" era sempre referida a manifestações tidas como artísticoculturais, cujo principal componente talvez fosse a tradição $e$ memória de tempos idos de "elegância, luxo, glamour e beleza" (Soliva, 2016:24), como caracterizou Thiago Soliva o processo de conquista de prestígio, por meio dos concursos de beleza, por aqueles/as que desde as décadas de 1960-70 exerciam alguma feminilidade em certames e competições diversas.

Enfim, uma história estava sendo, então, montada e uma memória recontada por relatos e fragmentos em torno dos concursos de beleza trans, em especial na cidade do Rio de Janeiro. Seja pela popularidade do formato dos concursos de beleza e do Miss Brasil entre homossexuais masculinos nas décadas de 1960 e 1970 (entre os quais parecia existir diversas travestis que ainda não haviam assumido por completo sua identidade feminina), seja pelos concursos "trans" realizados a partir dos anos 1970, parece que os concursos de miss foram considerados como um evento cultural simplesmente por serem reconhecidos como algo próprio por determinado grupo e parte constituinte de suas subjetividades e imaginário coletivo, o que 
colocava tais certames sob a vaga rubrica da "cultura trans". Um léxico ou corpus discursivo minimamente coerente parecia estar sendo construído, no qual cultura e identidade, juntamente com política e cidadania/direitos, poderiam compor determinado corpo junto às discussões trans, materializando tais noções junto à "população trans" e à sociedade de modo geral.

E a memória, talvez num sentido de tradição, pode ser vista como um importante elemento daquilo que aqui se quer chamar $e$ forjar como cultura, já que pode vir a ser um documento indelével $e$ uma reiterada atualização do sentido e imagem daquilo que determinado coletivo constrói e pensa de si e para si. Além disso, a memória sendo uma constante reconstrução do passado - que no presente é recontado sob o signo do afeto em novos contextos e para novos públicos - também pode ser pensada como essa mencionada tradição, cultura ou "enraizamento", segundo termo utilizado por Ecléa Bosi (2003), por ser um "passado concentrado no presente" (2003:186) capaz de "resguardar sonhos para o futuro" (2003:187). Nas palavras de Michael Pollak (1989:10), "o que está em jogo na memória é também o sentido da identidade individual e do grupo", sendo parte daquilo que é subjetivado como sua própria humanidade pelo grupo e por cada um de seus membros na relação passado, presente e futuro.

Histórias dos concursos de beleza trans da década de 1970 e diversas outras contadas nos bastidores do Miss $T$ Brasil por aquelas que se consideravam de gerações anteriores a das atuais misses foram muitas vezes compartilhadas em momentos de afeto, partilha e certa nostalgia, nos quais tais memórias foram reconstruídas por um generoso olhar para o passado. Agora que as "mais velhas" se encontram em uma situação de vida que poderíamos caracterizar como de estabilidade financeira, afetiva $e$ emocional, o passado parece ter ganhado outros tons e talvez possa, então, ser rememorado em toda sua positividade. E isso é possível pelo seu relato ressignificado no presente, pois, como afirma Ecléa Bosi (2003:20) apoiada em Walter Benjamin, "não esqueçamos que a memória parte do presente, de um presente 
ávido pelo passado, cuja percepção 'é a apropriação veemente de que nós sabemos que não nos pertence mais".

As memórias encarnadas em seus corpos e subjetividades e que desejam colocar em uma ação cultural ou em um concurso de beleza podem ser pensadas como o processo de criação de uma identidade pessoal e social, como discutido por Michael Pollak (1992:203):

\begin{abstract}
A construção da identidade é um fenômeno que se produz em referência aos outros, em referência aos critérios de aceitabilidade, de admissibilidade, de credibilidade, e que se faz por meio da negociação direta com outros. [...] Se é possível o confronto entre a memória individual $e$ a memória dos outros, isso mostra que a memória e a identidade são valores disputados em conflitos sociais $e$ intergrupais, e particularmente em conflitos que opõem grupos políticos diversos.
\end{abstract}

Todas essas memórias e a forma como são revividas $e$ relatadas fazem parte daquilo que pensam e constroem singularmente para si como a chamada "cultura trans", que diz diretamente de cada uma e todas. Além de ser afetiva e estética, essa "cultura trans" também pode ser política e politizada, como foi ao ser recontada no discurso do Miss $T$ Brasil acima mencionado. $\mathrm{Ou}$ no próprio palco em que as jovens travestis $e$ mulheres transexuais do presente desfilam desde o ano de 2012, literalmente colocando em cena o célebre verso da canção "Comida", composição de Arnaldo Antunes, Sérgio Brito e Marcelo Fromer para a banda Titãs, evocado em diversos momentos pelo "discurso nativo" do Miss T Brasil: "a gente não quer só comida, a gente quer comida, diversão e arte".

E talvez fosse exatamente isso que estava sendo dito ao se criar uma história para um concurso de beleza para travestis $e$ mulheres transexuais e a celebração de uma identidade trans em meio à diversão e à arte. Foram certas identidade e cultura, no sentido de tradição, que aquele grupo de travestis construiu para si como suas experiências, memórias e relato público de um passado 
glorioso dos concursos de beleza trans e espetáculos de travestis ocupando os principais teatros da cidade do Rio de Janeiro.

\section{Referências bibliográficas}

Aguiẫ, Silvia. Fazer-se no "Estado": uma etnografia sobre o processo de constituição dos "LGBT" como sujeitos de direitos no Brasil contemporâneo. Tese (Doutorado em Antropologia), Institudo de Filosofia e Ciências Humanas, Universidade Estadual de Campinas (Unicamp), 2014.

AlmeidA, Miguel Vale de. Corpo Presente-treze reflexóes antropológicas sobre o corpo. Oeiras, Celta, 1996.

Anderson, Benedict. Comunidades imaginadas. São Paulo, Companhia das Letras, 2008 [1983].

BALOGUN, Oluwakemi M. Cultural and Cosmopolitan: Idealized Femininity and Embodied Nationalism in Nigerian Beauty Pageants. Gender \& Society, vol. 26, n 3, 2012, pp.357-381.

BANET-WeISER, Sarah. The most Beautiful Girl in the World: Beauty Pageants and National Identity. Berkeley, Los Angeles, Londres, University of California Press, 1999.

BARBOSA, Bruno César. Nomes e Diferenças: uma etnografia dos usos das categorias travesti e transexual. Dissertação (Mestrado em Antropologia Social), Universidade de São Paulo (USP), 2010.

. Imaginando trans: saberes e ativismos em torno das regulações das transformações corporais do sexo. Tese (Doutorado em Antropologia Social), Universidade de São Paulo (USP), 2015.

BAtistA, Ana Maria Fonseca de Oliveira. O telefone sem fio, a sobrinha do presidente e as duas polegadas a mais - concepções de beleza no concurso Miss Universo. Dissertação (Mestrado em Antropologia Social), Universidade Federal de Santa Catarina (UFSC), 1997.

BenedetTI, Marcos. Toda feita - O corpo e o gênero das travestis. Rio de Janeiro, Garamond, 2005.

BosI, Ecléa. O tempo vivo da memória: ensaios de psicologia social. São Paulo, Ateliê Editorial, 2003. 
CARVAlHO, Mário Felipe de Lima. Que mulher é essa? Identidade, política e saúde no movimento de travestis e transexuais. Dissertação (Mestrado em Saúde Coletiva), Universidade Estadual do Rio de Janeiro (UERJ), 2011.

. "Muito prazer, eu existo!": Visibilidade e Reconhecimento no Ativismo de Pessoas Trans no Brasil. Tese (Doutorado em Saúde Coletiva), Universidade Estadual do Rio de Janeiro (UERJ), 2015.

; CARRARA, Sérgio. Em direção a um futuro trans? Contribuição para a história do movimento de travestis e transexuais no Brasil. Sexualidad, Salud y Sociedad-Revista Latinoamericana, $n^{\circ}$ 14, 2013, pp.319-351.

COHEN, Coleen Ballerino; WiLK, Richard; STOELTJE, Beverly. Introduction: Beauty Queens on the Global Stage. In: . Beauty Queens on the Global Stage. New York, London, Routledge, 1996.

CONNELL, Raewyn. Transsexual women and feminist thought: Toward new understanding and new politics. Signs, vol. 37, $\mathrm{n}^{\circ}$ 4, 2012, pp.857-881.

CosTA, Rogério da Silva Martins da. Sociabilidade homoerótica masculina no Rio de Janeiro na década de 1960: relatos do jornal O Snob. Dissertação (Mestrado em Bens culturais e projetos sociais), Fundação Getúlio Vargas (FGV), 2010.

CsORDAS, Thomas. Corpo/significado/cura. Porto Alegre, Editora UFRGS, 2008.

GREEN, James. Além do carnaval. A homossexualidade masculina no Brasil do século XX. São Paulo, UNESP, 2000.

KuLICK, Don. Travesti - prostituição, sexo, gênero e cultura no Brasil. Rio de Janeiro, Editora Fiocruz, 2008.

LANZ, Letícia. Arquivo Transgênero. [http://www.leticialanz.org - acesso em 22 set 2015].

LEITE JÚNIOR, Jorge. "Nossos corpos também mudam": sexo, gênero e a invenção das categorias "travesti" $e$ "transexual" no discurso científico. Tese (Doutorado em Ciências Sociais), PUC-SP, 2008.

LIMA, Daslan Melo. Sessão nostalgia -Maria Augusta Nielsen e a lenda de uma

bengala.

Passarela

Cultural,

2009 
[http://passarelacultural.blogspot.com.br/2009/11/sessao-nostalgiauma-lenda-do-miss.html - acesso em 07 jan 2016].

LOPES, Aureliano. Em desfile nossa terra, nossa gente?: a construção de corporalidades e belezas em concursos femininos diversos. In: Seminário Internacional Fazendo Gênero 10 - Desafios Atuais dos Feminismos, 2013, Florianópolis. Anais eletrônicos do Seminário Internacional Fazendo Gênero 10, UFSC, 2013 [http://www.fazendogenero.ufsc.br/10/resources/anais/20/1384955923 _ARQUIVO_AurelianoLopes.pdf - acesso em 25 set 2015].

MARCHI, Majorie. A Influência da "BELEZA" na formação das Identidades de Travestis e Transexuais brasileiras. Revista S!, vol. 123, ago 2012, p.14.

MARQUES, Fernanda. Em defesa dos direitos de travestis e transexuais. Agência Fiocruz de Notícias. 10 mai 2007 [[http://www.agencia.fiocruz.br/em-defesa-dos-direitos-de-travestis-etransexuais - acesso em 30 set 2015].

MIss Brasil Gay. Regulamento do concurso $35^{\circ}$ Miss Brasil Gay. [http://www.missbrasilgay.com - acesso em 05 dez 2011].

MISS T Brasil. [http://www.misstbrasil.com.br - acesso em 04 set 2012].

MITCHELL, Timothy. Society, economy, and the State effect. In: SHARMA, Aradhana; GUPTA, Akhil (orgs.). The anthropology of the state: $A$ reader. Oxford, Blackwell Publishing, 2006.

Moon, Scarlet; MotTA, Nelson. Linhas cruzadas. Jornal O Globo. Rio de Janeiro, 07 set 1974, p.31.

OCHOA, Marcia. Queen for a day: Transformistas, Beauty queens and the Performance of Femininity in Venezuela. Durham, Duke University Press, 2014.

POLLAK, Michael. Memória, esquecimento, silêncio. Revista Estudos Históricos, vol. 2, n 3, 1989, pp.3-15.

. Memória e identidade social. Revista Estudos históricos, vol. 5, $\mathrm{n}^{\circ} 10,1992$, pp.200-212.

RIO DE JANEIRO. Governo do Rio de Janeiro. Secretaria de Estado de Assistência Social e Direitos Humanos. Programa Rio Sem 
Homofobia [http://www.riosemhomofobia.rj.gov.br/ - acesso em 10 set 2015].

RoquetTe-Pinto. Ensaios de Antropologia Brasiliana. São Paulo, Companhia Editora Nacional, 1978 [1933].

SILVA, Hélio. Travesti - a invenção do feminino. Rio de Janeiro, RelumeDumará, 1993.

Silva, Pedro Pepa; VISNADI, Marcus; MoHAlleM, Gui. Diva que incomoda. Revista Geni [http://revistageni.org/06/diva-que-incomodaclaudia-celeste/ - acesso em 15 jul 2013].

SolivA, Thiago Barcelos. A confraria gay. um estudo de sociabilidade, homossexualidade e amizade na Turma OK. Dissertação (Mestrado em Antropologia Social), Universidade Federal do Rio de Janeiro (UFRJ), 2012.

- Sob o símbolo do glamour. um estudo sobre homossexualidades, resistência e mudança social. Tese (Doutorado em Antropologia Social), UFRJ, 2016.

TURMA OK. [http://www.turmaok.com.br - acesso em 16 ago 2017].

UMA noite de deslumbramento, lamês e defeitos técnicos. O Pasquim. Rio de Janeiro, Ano IV, n²72, 17 a 23 set 1974.

VencAto, Anna Paula. Sapos e princesas: prazer e segredo entre praticantes de crossdressing no Brasil. São Paulo, Annablume, 2013.

ZONA Pink. A evolução do concurso [http://www.acessa.com/zonapink/missgay99/evolucao.php - acesso em 22 set 2013]. 